\title{
Systematic Ice Retreat in New England
}

\section{GEOLOGICAL SURVEY PROFESSIONALAAPER 1179}

Prepared in cooperation with the Neic Hamipsive

Department of Resources and Economic Development,

Connecticut Geological and Nalural History Survey,

Department of Envimnmental Profection, and

Commonieculth of Massailiusetts Defaurtinent of Public Woiks

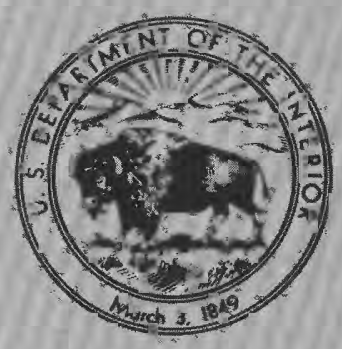




\section{Systematic Ice Retreat in New England}

By CARL KOTEFF and FRED PESSL, JR.

\section{GEOLOG ICAL SURVEY PROFESSIONAL PAPER 1179}

Prepared in cooperation with the New Hampshire

Department of Resources and Economic Development, Connecticut Geological and Natural History Survey,

Department of Environmental Protection, and

Commonwealth of Massachusetts Department of Public Works

$A$ discussion of more than 100 years

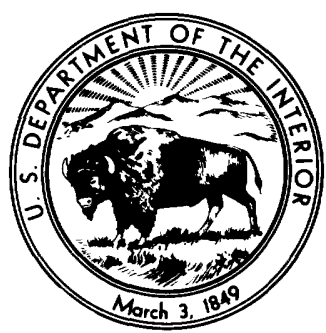

of debate on the nature of retreat

of the late Wisconsinan ice sheet

from the region 
UNITED STATES DEPARTMENT OF THE INTERIOR

JAMES G. WATT, Secretary

GEOLOGICAL SURVEY

Doyle G. Frederick, Acting Director

Library of Congress Cataloging in Publication Data

Koteff, Carl.

Systematic ice retreat in New England.

(Geological Survey professional paper ; 1179)

Bibliography: $p$.

Supt. of Docs. no.: I 19.16:1179

1. Glacial epoch-New England. I. Pessl, Fred, joint author. II. New Hampshire. Dept. of Resources and Economic Development. III. Title. IV. Series: United States. Geological Survey. Professional paper ; 1179. QE697.K678 $551.7^{\prime} 92^{\prime} 0974$ 80-607063

For sale by the Superintendent of Documents, U.S. Government Printing Office Washington, D.C. 20402 


\section{CONTENTS}

$\begin{array}{lr}\text { Abstract } & \\ \text { Introduction } & \text { Pige } \\ \text { Previous work } & 1 \\ \text { Morphosequence concept } \\ \text { Types of sequences }\end{array}$

\section{ILLUSTRATIONS}

Figlikt 1. Diagrammatic profiles of morphosequences

2. Profiles of four fluvial ice-contact morphosequences in the Pepperell quadrangle, Massachusetts and New Hampshire

3. Map of part of the Springfield South quadrangle, Massachusetts and Connecticut, showing downvalley lobation of two retreatal positions of ice

4. Photographs of fault structures in two areas of collapsed glacial-lake sediments, Merrimack, N.H.

5. Photograph of slump features in sediments of glacial Lake Merrimack, Manchester, N.H.

6. Map showing distribution of Wisconsinan moraines and ice-readvance localities in New England

7. Photograph of till overlying sheared and rotated glacial-lake bottom sediments, Manchester, N.H.

8. Profiles of four successively younger lacustrine ice-contact sequences (kame deltas) in the Clinton quadrangle, Massachusetts_

9. Photographs of modern Alaskan glaciers showing debris-rich terminal zones and clean ice upglacier to the firn line

10. Photograph showing scree on the Casement Glacier, Glacier Bay National Monument, Alaska

11. Photograph of detached ice block, Casement Glacier

12. Diagrammatic profile of margin of retreating ice

13. Photographs showing shear planes containing debris, Casement Glacier

14. Photographs showing debris on Casement Glacier derived from shear planes near the area shown in figure 13

15. Photographs of the Casement Glacier showing a thin surface accumulation of morainal debris near the center of the glacier and debris at the edge of the glacier which is interpreted to be derived chiefly from the "dirt machine" 



\title{
SYSTEMATIC ICE RETREAT IN NEW ENGLAND
}

\author{
By Carl Koteff and Fred Pessl, JR.
}

\begin{abstract}
The mode of ice retreat after the maximum advance of the Wisconsinan glacier that last covered New England has been a subject of controversy for more than 100 years. Two major opposing views during most of this period focused on whether recession was characterized by systematic retreat of active glacier ice or by regional stagnation. Difficulty in correlating with the well-established ice-recessional history in the Middle West hampered the discussion in New England. In the last few decades, detailed mapping on large-scale topographic maps has formed the basis for a third model of deglaciation, the morphosequence concept, which contains parts of both previous views. Careful outlining of the distribution and age relationship of melt-water deposits shows that the ice sheet receded by a process of stagnationzone retreat and that the region was deglaciated systematically. End moraines and readvance localities that demonstrate the presence of live ice during retreat in New England are relatively scarce; however, the distribution of such localities indicates that live ice was only a few kilometers from the margin throughout recession.

The position, volumes, and especially the altitudes of melt-water deposits suggest that their source material was debris at or near the ice surface. The debris was carried upward from englacial positions to the ice surface along shear planes that resulted from live ice moving over the obstructing stagnant ice at the glacier margin. Analogous shear planes carrying debris have been found in modern valley glaciers.
\end{abstract}

\section{INTRODUCTION}

The mode of deglaciation following maximum advance of the last ice sheet to cover New England has been a matter of controversy for more than 100 years. Opposing views regarding the configuration of the waning ice sheet; the condition of the ice, whether active or stagnant; and the rhythm of deglaciation, whether systematic and orderly or random and chaotic, have repeatedly been argued in the literature. In recent years, additional attention has been given to the problem of the sediment source for glacial deposits. Did stagnant ice, cut off from the main active ice mass, contain sufficient debris to account for the large volumes of glacial sediment present in many parts of New England, or do such volumes require a sediment source at the margin of the active ice, where it is continually replenished by debris from the moving ice mass?

Since the 1940's, U.S. Geological Survey field studies have emphasized the detailed delineation of glacial meltwater deposits that establish relative chronologies within single drainage systems; these studies support the concept of systematic northward retreat of an active ice sheet fringed by a marginal zone of stagnant ice (stagnation-zone retreat). Recently, however, some workers have suggested otherwise: that inland from the coastal area, where the presence of recessional moraines is well established, evidence of ice-margin postitions is lacking (Flint and Gebert, 1976); they suggested that large inland areas were characterized by regional stagnation during which glacial sediments were derived locally from isolated, dead-ice masses (Black and Frankel, 1976; Black, 1977). In this paper, we review the history of this controversy and attempt to show that the nature and distribution of glacial deposits throughout most of New England support the concept of systematic northward retreat of an active ice sheet and that discrete ice-margin positions can be identified.

The conceptual framework now being used by most U.S. Geological Survey geologists to study and map water-laid glacial deposits in New England is a consequence of changing ideas on the manner in which the last continental ice sheet disappeared from New England. Early emphasis on "normal retreat," the gradual melting back or calving of a well-defined and steeply sloping face of live ice, resulted from the natural inclination of geologists to interpret New England glacial history in light of the midwestern glacial stratigraphy, which was based on detailed mapping of recessional moraines in the Great Lakes region. As mapping progressed in New England and recessionalmoraine deposits were not readily identified, the inappropriateness of the analogy with the Midwest gradually became apparent.

Widespread distribution of ice-contact stratified drift throughout much of New England and the apparent absence of significant recessional moraines inland from the coast led to the concept of regional stagnation, where deglaciation resulted in the dissipation of the ice as a stagnant mass while at or near its maximum southward extension. In this view, downwasting thinned the ice sheet to the extent that topographic barriers in areas of high to moderate relief were sufficient to induce widespread stagnation. 
These two hypotheses, "normal retreat" and "regional stagnation," presented rather opposing views of the process of deglaciation, and as often happens, a third view evolved somewhere between the two extremes. The distribution of ice-contact deposits at the heads of graded melt-water deposits, which appeared to be progressively younger northward, suggested that the border of the last ice sheet may have retreated as a narrow stagnant zone. This hypothesis of stagnation-zone retreat is based on detailed mapping of water-laid glacial deposits and brings together the conflicting views on the process of deglaciation.

\section{PREVIOUS WORK}

During the latter part of the 19th century, mapping of glacial deposits in New England had progressed so that a prevailing view of the mode of ice retreat could be detected in the literature. As a result of his study of melt-water deposits in New Hampshire, Upham (1878, p. 175) visualized a gradual retreat of the last ice sheet at varying rates. Emerson's (1898) map of the glacial deposits in old Hampshire County, Mass., shows positions of the ice front, called "ice barriers," and indicates that they are progressively younger to the northwest. Emerson (1898, p. 563), in his history of the Champlain Period, referred to positions of an ice front that in its northwestward retreat locally uncovered progressively lower spillways and thereby controlled the altitudes of extensive proglacial drainages. Similarly, Stone (1899) published an isochrone map of Maine showing approximate positions of the ice front based on a tentative correlation of features considered diagnostic of a lobate ice front during retreat. Woodworth's (1898, p. 111) research in southern New England indicated that the main part of the last ice sheet remained active during retreat.

Crosby's $(1899$, p. 292, 312) study of the late-glacial history in the Nashua Valley, Mass., also invoked the concept of systematic northward retreat of a distinct ice front to explain the history of glacial Lake Nashua and its deltaic deposits. However, in a more detailed consideration of the Clinton stage of the glacial lake, he $(1899$, p. 322) noted the scarcity of recessional moraines and suggested that stagnation had apparently been widespread, perhaps because of strong topographic gradients in the area. Dana $(1873$, p. 203, 210), in his discussion on the Glacial and Champlain Eras, attributed the absence of distinct terminal moraines in New England to widespread melting of the glacier surface, instead of concentrated melting at the glacier margin. Thus, by the end of the 19th century, the majority view seemed to favor systematic retreat of an active ice front, but there were important dissenting opinions, particularly regarding the existence, distribution, and significance of ice-marginal deposits.

In the early 1900 's, many papers appeared in which the authors argued in favor of normal retreat in areas of eastern and central Massachusetts (Goldthwait, 1905; Alden, 1924), New Hampshire (Goldthwait, 1925), and central New England (Antevs, 1922). Goldthwait's (1905) important early study in the Sudbury Valley, Mass., was firmly based on the interpretation of normal retreat and systematic uncovering of successively lower drainage divides. He concluded that the area had contained a series of proglacial lakes at successively lower levels. In a later paper, Goldthwait $(1925$, p. 33$)$ described the wasting ice sheet in lowland coastal areas of eastern New Hampshire and compared the deposition of massive ice-marginal ridges there with the great terminal moraine and outwash apron of Long Island, N.Y. He $(1925$, p. 29) described wasting of the ice sheet farther inland, in areas of higher topographic relief, as consisting of "(a) a melting back of its edge at rates usually between 200 and 600 feet a year; and (b) a thinning out of the sheet by slow downward melting to its surface so as to expose the mountain tops and hillsides and leave irregular tongues of ice in the valleys."

Antevs' work in central New England, where he applied De Geer's technique for correlating varved-clay layers from one locality to another, was also based on the interpretation of systematic northward retreat of an active ice front. Antevs' (1922) study, however, involving painstaking measurements of many stratigraphic sections in clay pits and natural exposures primarily along the Connecticut River, introduced a new approach that seemed to identify precise rates of glacier recession, to reconstruct ice-margin positions during each year of recession, and to identify stillstands of the ice border, even where no recessional moraines were present. J. W. Goldthwait was particulary supportive of Antevs' work and noted (in Antevs, 1922, p. ix) that "He [Antevs] has worked out successive positions of the receding ice border in a region where two generations of American geologists, baffled by the absence of definite moraines, have realized little or no success."

Although many of the features in central Massachusetts that Alden (1924) described as moraines are today interpreted as ice-contact heads of outwash (Schafer and Hartshorn, 1965, p. 120), his interpretations regarding deglaciation remain of interest. Alden $(1924$, p. 93) stated that the glacier margin melted slowly back from south to north and argued that " *** the ice did not disintegrate throughout the area as a wholly stagnant mass, but $* * *$ the retreat of the glacial front was effected by a series of stages, with intermittent halts and slight marginal accumulations of drift."

However, the early 1900's also had advocates of 
widespread stagnation: Salisbury and others (1902) in New Jersey; Clapp (1904) and Fuller (1904) in Massachusetts; and Fuller (1914) and Cook (1924) in New York. Clapp (1904, p. 198) concluded from his study of glacial Lake Charles, Massachusetts, that the ice stagnated many miles back from the ice margin and that the dead ice was covered by widespread deposits of sand and gravel.

Fuller (1904, p. 181) concluded in his report on studies of glacial Lake Neponset in eastern Massachusetts that the ice in that region had become completely stagnant before the lake formed. He (1904, p. 192) cited the lack of moraines and the lack of structures within the deposits indicative of forward motion of the ice (that is, the absence of folding and faulting) as evidence favoring stagnation. Later, Fuller (1914, p. 212) reported that he had also found evidence of widespread stagnation in Long Island, N.Y., and attributed cessation of glacier movement to an ameliorating climate.

Perhaps the most outspoken advocate of widespread stagnation at this time was Cook, who reported (1924, p. 158-159) on the disappearance of the last ice sheet from eastern New York:

"As the field work progressed it became evident that the region could not be interpreted in accordance with the generally accepted theory of the 'retreat' of the last continental ice sheet, namely: the gradual melting back of a fairly definite face of live ice.

"As the inquiry was pushed into various critical regions the ice front became more and more fictitious and the evidence of wide areas of stagnant ice more and more convincing."

Cook also found that recessional ice-marginal features were generally absent and that evidence for thick masses of stagnant ice was commonly present downstream from any inferred position of a retreating ice front. He $(1924$, p. 163) anticipated some of the current work in New England with his remark: "Lacking the direct evidence of recessional moraines, some indirect evidence ought to be furnished by an application of the ice-front hypothesis to interference with the normal land drainage; there should be found: the records of ponded waters with lowering outlets at predictable points over cols or across land salients as the assumed ice front withdrew."

In 1927, R. F. Flint began his study of the glacial geology of Connecticut; later, he published his reports summarizing the results of the field studies and setting forth the most complete and influential arguments in favor of regional stagnation. These papers (Flint, 1929, 1930), and a subsequent paper (Flint, 1932) in which some of the interpretations regarding stagnation were revised, had a profound effect on those concerned with glacial geology in the northeastern United States. Flint's eloquent and forceful advocacy of regional stagnation dominated the thinking of glacial geologists for several decades. In his earlier papers $(1929,1930)$, Flint confronted the longstanding controversy head on, albeit from a study area limited primarily to Connecticut. He stated (1930, p. 56): "All of the evidence within Connecticut points clearly to the conclusion that when the glacier had reached its maximum southward extent, it lost its forward thrust and lay stagnant, slowly rotting away in place until at length it disappeared. This manner of melting stands in sharp contrast with the slow northward retreat of an ice front through Connecticut which has hitherto been assigned to the last ice sheet."

Flint (1930, p. 58-59) listed the following objections to the concept of normal retreat: 1) the lack of recessional moraines; 2) the lack of outwash plains sloping southward from the ice front that have ice-contact heads sloping to the north; 3 ) the lack of evidence of active-ice deformation in deposits of till or outwash; and 4) the presence of untrimmed ice-contact slopes flanking the valleys, indicating little or no erosion of older deposits to the south by melt water from melting ice to the north. Furthermore, he argued (1930, p. 63-64) that field evidence was, without exception, consistent with the concept of regional stagnation; he noted especially flatlying terraces that had ice-contact slopes facing in all directions, indicating that the ice did not recede systematically in any one direction but rather shrank radially from valley walls.

Taylor (1931), on the other hand, castigated "certain geologists" for advocating regional stagnation because moraines and other features comparable with those in the Great Lakes region were not recognized in New York and New England. He wrote (1931, p. 334), "Moraines and border drainage features were found in abundance, but they are very different from those in the West. Nearly all are short fragments, largely terminal deposits of narrow ice tongues, with many kames and sometimes with banked moraine deposits on the hillside, and also with associated marks of border drainage. It is difficult in some parts to make out continuous positions of alignment of the ice front, but the features show oscillating retreat as clearly as they do in the West."

Much of Flint's argument had been stated previously by other workers, although the emphasis on a detailed field study of terraces and ice-contact deposits was new. However, these new elements of the argument were challenged most vigorously by some critics and were subsequently modified by Flint (1932). Principal among these modifications were the identification of southdipping gradients on outwash surfaces that he had thought earlier to lie flat and the recognition of erosional slopes and scarps where earlier interpretation had 
indicated primary ice-contact slopes. The post-depositional erosional effects of melt water derived from ice still existing within a glacial drainage system complicated the concept of large-scale regional stagnation, and Flint (1932, p. 156) responded," ${ }^{* * *}$ a third hypothesis $* * *$ that during the deglaciation of Connecticut, the ice margin wasted northward, but that through an unknown distance inward from the periphery, the ice was chiefly stagnant." Unfortunately, Flint's modifications of his earlier interpretations and, particularly, his sense of a third hypothesis seem to have been forgotten. The third hypothesis clearly anticipates the idea of stagnation-zone retreat, which at present seems best to explain the process of deglaciation in New England. However, after publication of Flint's reports on the glacial geology of Connecticut, both opponents and proponents focused on his earlier interpretations, and the controversy continued.

One of the most profound effects of Flint's ideas is seen in the reaction of J. W. Goldthwait. Previously, Goldthwait $(1905,1925)$ had worked extensively in New England describing proglacial-lake systems, end moraines, and readvance localities and, in general, documenting evidence for the gradual northward retreat of the ice margin. Goldthwait was stimulated by Flint's work to reevaluate his interpretation of lateglacial events in New Hampshire. Supplied with more detailed topographic base maps, he substantially changed his earlier interpretations and completely revised his theory of the way the last ice sheet disappeared. He (1938, p. 371) described, for example, the random orientation of ice-contact features and noted that" ${ }^{* * *}$ we are not dealing with one continuous ice edge that receded in orderly fashion across country, but rather with a maze of downwasting, thinning ice which lay stagnant or nearly so when these gravels and sands finally accumulated, occupying areas so utterly ragged in outline and so unstable in pattern that one can hardly reconstruct successive stages of ice removal on the maps."

In contrast to Goldthwait's ardent support of Flint's ideas, Antevs (1939) took strong exception to them. He (1939, p. 506-507) envisioned a distinct, gently to steeply sloping ice margin characterized by wastage at the ice border due primarily to melting and evaporation, and he thought that interior ablation (evaporation and outflowage) had resulted in a lowered ice surface. Antevs (1939) acknowledged the existence of a marginal belt of stagnant ice but noted that it probably occupied only a part of the zone of melting; he $(1939$, p. 507) further emphasized that "The fact that a belt of dead-ice topography may be 25 or more miles wide does not imply that there was so broad a belt of stagnant ice at any one time."
Reporting on his studies in the Housatonic Valley, western Massachusetts, Logan (1938, p. 55) also argued in favor of an active ice sheet during recession but noted that ice-margin deposits such as kames and heads of outwash were discontinuous in areas of high topographic relief and that correlation of these deposits was difficult. He envisioned a very irregular ice margin consisting of long narrow lobes extending downvalley.

In 1934, Flint's study of the Quinnipiac-Farmington lowland in Connecticut was published; in it, the author described ice-contact deposits, varved clay, and postglacial terrace deposits in the context of widespread stagnation. Lougee in 1938 reported on his study of the same area and offered an alternative interpretation of late-glacial events in which systematic northward retreat of the ice controlled the formation of a series of proglacial lakes and the sequence of deposition of fluvial gravels. In 1940, Lougee published "Deglaciation of New England" in which he contradicted many of the reinterpretations of features in New Hampshire offered by J. W. Goldthwait (1938) in support of stagnation and downwasting. Lougee (1940, p. 191-192) defended Antevs' varve chronology, particularly in northern New England, and cited Antevs' (1922) study as demonstrating progressive northward retreat of the ice sheet. Lougee acknowledged that recessional moraines as evidence of active ice were notably scarce in New England and suggested that the rugged topography and rapid rates of retreat were possible reasons. However, he was unwilling to discount several reported moraines that Goldthwait, in his reinterpretation (1938, p. 348-352), had discredited. Lougee (1940, p. 193-194) acknowledged that some earlier interpretations of localities attributed to active ice deformation and deposition merited revision, for example, the AmherstNorthampton evidence in Massachusetts and the Claremont "readvance" in New Hampshire. However, Lougee $(1940$, p. 195) maintained that other localities such as the Littleton-Bethlehem, N.H., moraine system and associated exposures showing till sheets separated by stratified deposits remained firm testimony to the presence of active ice during retreat. In addition, Lougee interpreted ice-contact stratified sediments alined northwest in the coastal region of New Hampshire as deposits of glacial melt water issuing from the ice margin and flowing at right angles to the retreating ice front. Goldthwait considered these deposits as resulting chiefly from deposition in irregular pools and broad channels produced by the uneven downwasting of the glacier surface. Other deposits such as pitted coastal clays, interior-valley outwash, and the widespread icecontact sediments in the White Mountains also were interpreted differently by Lougee and Goldthwait (Lougee, 1940, p. 199-213). 
Douglas Johnson (1941) attempted to clarify a problem that he considered to result largely from semantic difficulties related to the longstanding controversy. $\mathrm{He}$ emphasized that "retreat" refers only to the position of the ice margin and that "downwasting" refers only to the ice mass, never to the position of the margin. Johnson (1941, p. 85-90) also pointed out (1) that the presence or absence of recessional moraines depends on the interaction of several variables: topographic relief, rate of glacier flow, rate of ice wastage, and sediment source; and (2) that the absence of recessional moraines does not mean that the ice margin was not retreating, but rather that retreat was too continuous for moraines to form.

Unfortunately, Johnson's arguments depended to some extent on an oversimplified comparison of conditions on an alpine glacier with those on a continental ice sheet. He also tended to discount the distinctive nature of ice-contact deposits (Woodworth, 1899; Thwaites, 1926; Flint, 1928) and their importance as indicators of stagnant-ice conditions, thus rejecting an important field criterion for identifying distribution and nature of the local ice regimen. Johnson acknowledged that the debris-laden margin of a wasting continental glacier is likely to produce isolated masses of stagnant ice, but he (1941, p. 94) considered defining the former extent of such masses in New England an unreasonable prospect. Johnson (1941) recalled an argument by Antevs (1939, p. $507)$ that "A zone of stagnant ice one hundred miles broad, and a zone of stagnant ice a mile broad receding with the ice margin over a belt one hundred miles broad, may leave fluvio-glacial phenomena of like character." Johnson concluded (1941, p. 94), "Whether the two histories can be discriminated from examination of the residual deposits and forms must remain in doubt until highly critical studies have been made."

In recent decades, detailed mapping on large-scale topographic bases (most at 1:24,000 scale and most having 10 -ft (3-m) contour intervals) has been completed for extensive areas in Massachusetts, Rhode Island, Connecticut, and New Hampshire. In addition, several notable discussion papers have been published in which the authors presented new ideas on the question of deglaciation in New England (Jahns, 1941, 1953; Currier, 1941; Rich, 1943; White, 1947; Schafer, 1961; Schafer and Hartshorn, 1965; Koteff, 1974). It now seems reasonable to suggest that since the early 1940's, just such "highly critical studies," as envisioned by Johnson (1941, p. 94), have been made in southern and central New England, that the cumulative results of this work do permit definition of a stagnant zone that migrated northward during deglaciation, and that a plausible model of deglaciation, incorporating elements of both normal retreat and downwasting accompanied by stagnation, has evolved.

This model, now called the morphosequence concept, was first advanced by R. H. Jahns (1941, 1953), on the basis of field studies in north-central Massachusetts. His work was plotted on newly introduced, accurate, $7 \frac{1}{2}$-min topographic maps at a scale of $1: 31,680$, having a $10-\mathrm{ft}(3-\mathrm{m})$ contour interval. These maps allowed Jahns to make a very detailed analysis of the morphology, texture, and distribution of melt-water deposits. The importance of the introduction of these new maps in the early 1940's cannot be overemphasized because they provided a source of data previously unavailable to protagonists of either normal retreat or regional stagnation. The enthusiasm of glacial geologists regarding the 1:31,680-scale maps matched that of J. W. Goldthwait in 1905 regarding the then-new 15-min topographic maps for the Concord, Mass., area, where he thought orderly retreat of the ice sheet was well demonstrated. Ironically, when he later began to favor regional stagnation, he $(1938$, p. 346$)$ mentioned, " *** complete contour mapping of New Hampshire $* * *$ " on a 15-min base had "afforded better opportunity to judge the relative importance of downward and backward melting of the ice."

\section{MORPHOSEQUENCE CONCEPT}

Since Jahns introduced the sequence concept in 1941, some confusion has existed about what sequences are because the word "sequence" has a connotation of time that was not originally intended. In the concept, a single sequence specifically refers to a continuum of landforms composed of melt-water deposits, from more collapsed forms due to melting of ice blocks at the head or upstream parts of outwash, to progressively less collapsed forms downstream. A sequence can thus be viewed as a body of stratified drift laid down, layer upon layer, by melt water at and beyond the margin of a glacier, while deposition was controlled by a specific base level. The complexity of the morphologic features depends on the relative number, size, and distribution of detached ice blocks around and over which the sequence was deposited. For example, at the head of outwash near or at the ice margin, a sequence may be composed of typical ice-contact features, such as ice-channel fillings and kames, which show a considerable amount of collapse; downstream, the less collapsed forms may be kame terraces or kame plains, and beyond any area of residual ice blocks, the form may be an outwash plain. All the forms in this continuum are regarded as part of one time unit and, thus, the word sequence in this sense does not refer to a span of time but to a progression of more collapsed to less collapsed contemporaneous forms. One individual sequence has a time significance 
only in relation to other sequences. Although another word originally may have been more desirable to avoid confusion, the term "sequence(s)" has been established too long in the literature on New England glacial deposits to be abandoned completely.

In an effort to clear up some of the confusion and still retain the term "sequence," Koteff (1974) introduced the term "morphologic sequence." Since then, W. C. Mahaney (1976) has suggested a term that we think is even more suitable. Mahaney $(1976, \mathrm{p}$. vi) referred to J. H. Hartshorn's description ${ }^{1}$ of New England melt-water deposits as " $* * *$ morphosequences of time-equivalent groups of landforms." Mahaney's objection (written communication, 1979) that the term "morphologic sequence" is too closely related to terminology used by pedologists to indicate changes in soil configuration with time, appears to us to be well taken. Thus, we hereby endorse the term "morphosequence" to describe the concept originally introduced by Jahns in 1941. In this paper, morphosequence and sequence are used interchangeably.

\section{TYPES OF SEQUENCES}

The first application of the sequence concept to meltwater deposits by Jahns (1941) dealt primarily with fluvial sediments, but the model now includes lacustrine and marine deposits as well, and eight major types of morphosequences are presently identified (Koteff, 1974). Types of sequences are distinguished (fig. 1) on the basis of whether they were deposited in a fluvial, lacustrine, or marine environment, of whether they were in contact with the stagnant-ice margin, and of whether they had an associated end moraine.

\section{PHYSICAL CHARACTERISTICS OF SEQUENCES}

Textural distribution.-Each morphosequence is much like any water-laid unit, in that the texture at the surface of the deposits is coarser near the head of outwash or source and becomes finer grained downstream. The textural boundaries are not always sharp or easily distinguished; locally, within any given morphosequence, gravel can be found in an area of finer textures, or sand can be found in an area of gravel. Also, very short sequences show little textural change from one end to the other; some have only gravel at the surface and some have only sand, depending on the nature of the source material and, perhaps more importantly, on the depositional gradient. However, textural gradation downstream from the headward source area is generally persistent for the entire length of most sequences.

$1 \mathrm{~J}$. H. Hartshorn, address to the Conference on Quaternary Stratigraphy of North America at York University, Downsview, Ontario, Canada, 1975.
Base-level controls. - The determination of a base-level control for deposition is as important in distinguishing one morphosequence from another as is locating the origin or head of outwash of sequences. Base-level controls include spillways underlain by bedrock or till, previously deposited masses of sand and gravel (mostly older sequences), standing-water bodies such as glacial lakes (which in turn were controlled by a separate spillway) or even the sea, and stagnant-ice masses. Live ice has not been identified as having acted as a base-level control in New England. Spillways underlain by bedrock clearly were the most durable, whereas those underlain by glacial drift were more subject to varying degrees of erosion. However, some spillways underlain by sand and gravel appear to have lasted for a significant time; for example, the one that presumably was the outlet for a glacial lake in Cape Cod Bay (Oldale, 1974) was used during the time several consecutive sequences were constructed. Factors that may have contributed to such durable spillways in sand and gravel are the possible presence of ice-cored drift and a very shallow downstream gradient that may have retarded headward erosion of the spillway.

Profiles.-Topographic profiles drawn in a general downstream direction can aid in distinguishing one morphosequence from another. Figure 2 shows profiles of four successively younger fluvial ice-contact sequences near Dunstable, Mass. (Pepperell quadrangle, Mass.-N.H.) The profiles were constructed by projecting at right angles to an approximated longitudinal centerline maximum altitudes of deposits within approximately $600 \mathrm{~m}$ on either side of the centerline. This method produces a reasonable representation of the precollapse surface by smoothing out the irregularities in deposits where adjacent or buried ice blocks melted out, as well as irregularities caused by postdepositional erosion. The idealized gradients shown in figure 2 are straight-line segments, which appear to be most common for sequences mapped in New England, although upward curving of the profile near the heads of outwash is found in many deposits where collapse has not been too extensive. Profiles are very helpful in indicating the relative ages between sequences within a single drainage system, especially when used with textural data that show the relative downstream gradation of coarse to fine clast sizes.

\section{TOPOGRAPHIC CONTROL OF SEQUENCES}

The distribution, position, and shape of morphosequences were closely controlled during their deposition by the topography of New England, an important factor in unravelling the chronology of ice retreat in the region. Local relief appears to have had a close relationship with ice thickness, as reflected in the amount of 


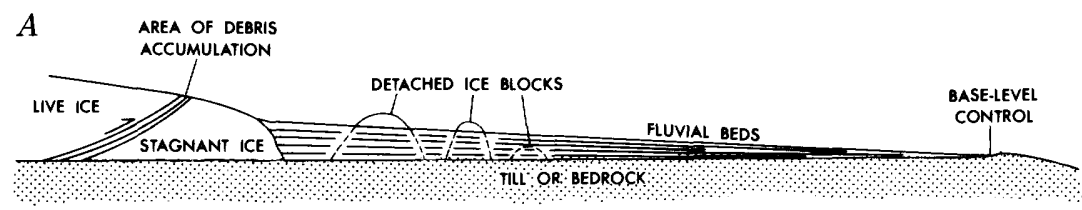

\section{$B$ AREA OF DEBRIS}
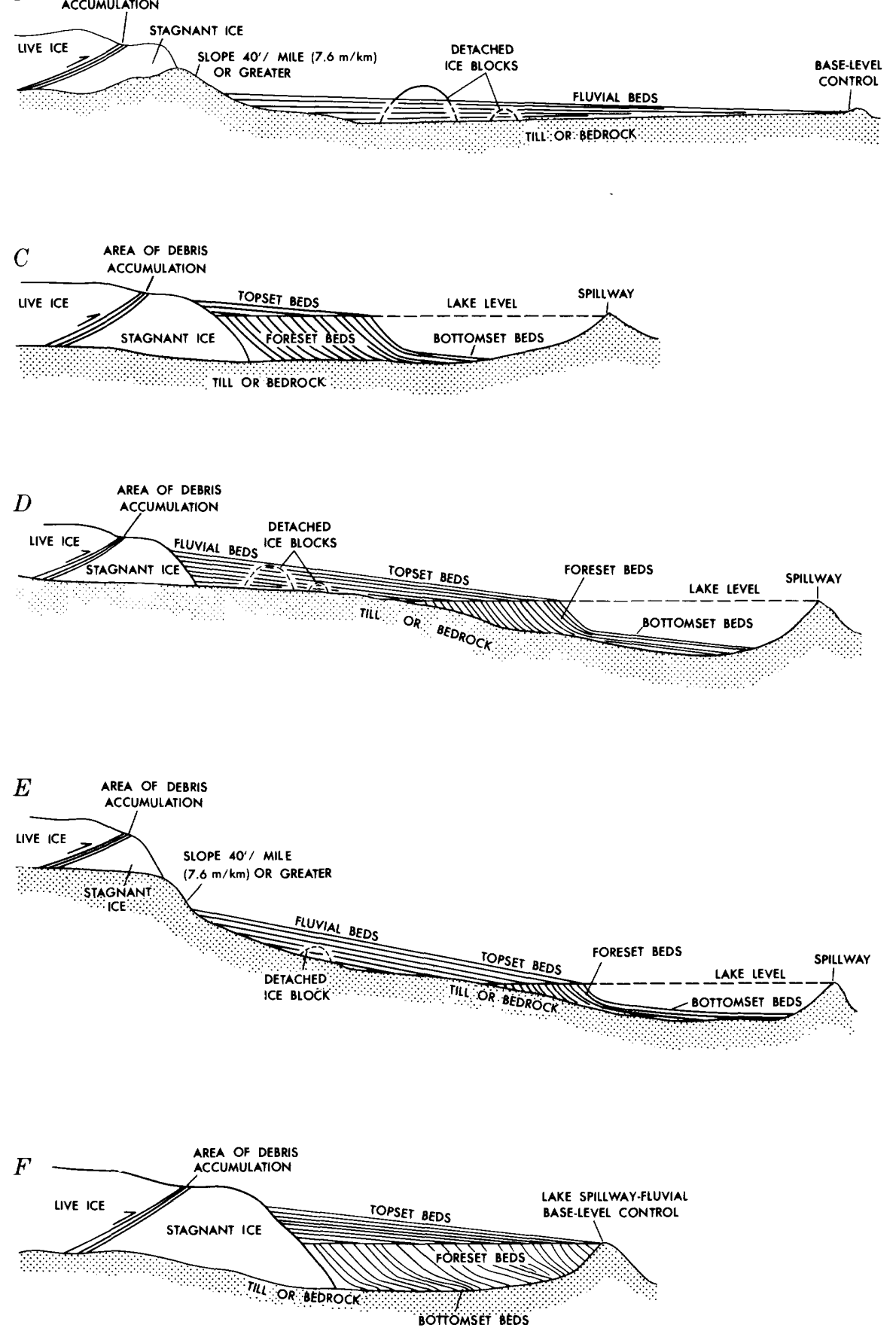

FIGURE 1. Diagrammatic profiles of morphosequences (Koteff, 1974, p. 128-129). Detached ice blocks and stagnant ice masses are sites of future collapsed ice-contact slopes. $A$, Fluvial ice-contact sequence. $B$, Fluvial non-ice-contact sequence. $C$, Lacustrine ice-contact sequence. $D$, Fluvial-lacustrine ice-contact sequence. $E$, Fluvial-lacustrine non-ice-contact sequence. $F$, Lacustrine-fluvial ice-contact sequence. Not shown are sequences representing a marine environment and sequences associated with an end moraine. 


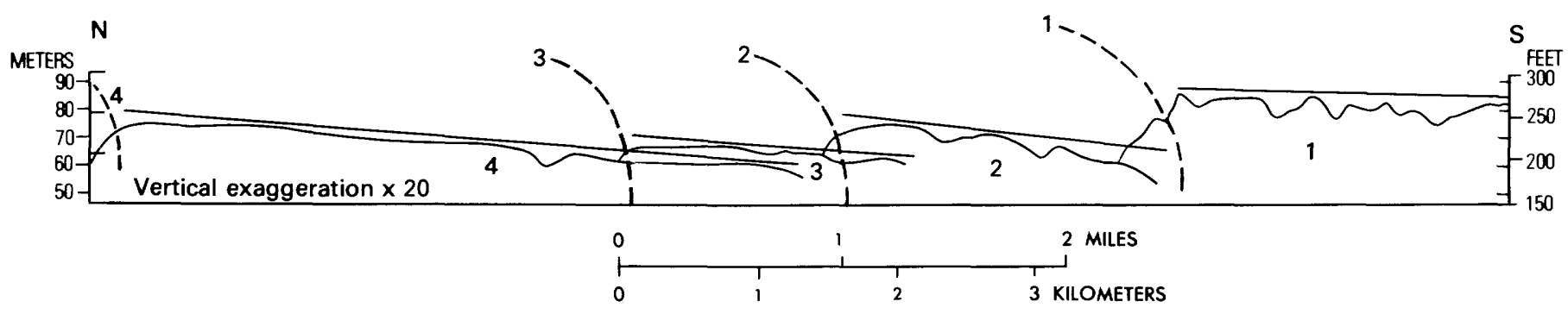

Figuke 2.-Profiles of four fluvial ice-contact morphosequences in the Pepperell quadrangle, Massachusetts and New Hampshire. Sequence 1 is the oldest. Solid-line tangents indicate an idealized gradient for the sequences; base-level controls are south and east of the area. Dashed lines represent successive positions of the stagnant ice front; numbers refer to related sequences. Modified from Koteff and Volckmann (1973).

lobation at the ice margin, particularly in the larger valleys. For example, stagnant-zone deposits and a later morphosequence near Springfield, Mass. (fig. 3), outline two positions of a lobe that extended about $8 \mathrm{~km}$ downvalley. The Connecticut Valley in this area has a relief of about $275 \mathrm{~m}$, a width of about $24 \mathrm{~km}$, and a regional slope of less than $1 \mathrm{~m} / \mathrm{km}$. Langer (1977) has demonstrated that ice recession farther south in the Connecticut Valley near Glastonbury, Conn., was simultaneous both upvalley and away from the valley walls. As the retreating stagnant-ice margin uncovered lower and lower outlets along the eastern valley border, correspondingly lower morphosequences were deposited; these deposits parallel the major structural and topographic northeast trend of the valley wall. Other valleys in New England of lesser relief and width show correspondingly less lobation of the ice margin. During retreat of the ice in the southern Merrimack Valley in New Hampshire, for example, the ice margin was lobate downvalley for about $2.5 \mathrm{~km}$; the valley in this area is about $8 \mathrm{~km}$ wide and has a regional slope of less than $1 \mathrm{~m} / \mathrm{km}$.

Topographic control of the distribution and position of morphosequences cannot be demonstrated for all areas in New England because many upland areas contain no melt-water deposits at all. However, wherever morphosequences are found throughout New England, even slight topographic irregularities have influenced their shape, position, and distribution by providing temporary basins and outlets or base-level controls for melt water. There are some notable examples in which melt-water deposits themselves dammed valleys; for example, the drift dam for glacial Lake Hitcheock at Rocky Hill, Conn. (Flint, 1933, p. 977-978; Jahns and Willard, 1942, p. 281). The dams created depositional basins and outlets for later sedimentation, but the positions of these drift dams were controlled by the local topography.

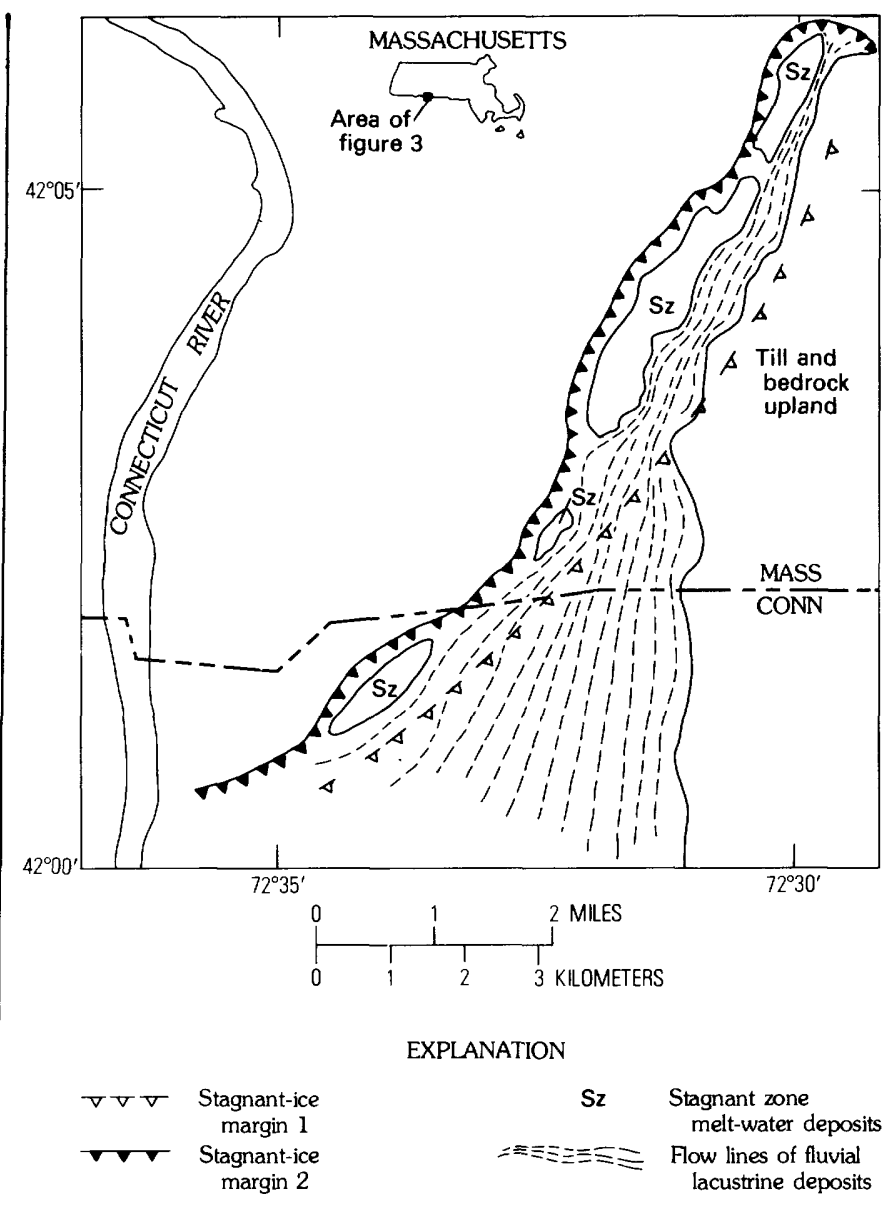

FIGURE 3.-Part of the Springfield South quadrangle, Massachusetts and Connecticut, showing downvalley lobation of two retreatal positions of ice. Stagnant-zone deposits were laid down entirely within the stagnant margin during the earlier and more southerly retreatal ice position. Modified from Hartshorn and Koteff (1967). 


\section{STAGNATION-ZONE RETREAT}

\section{EVIDENCE FOR A STAGNANT MARGIN}

The most conspicuous features that mark retreatal ice positions in New England are the heads of outwash of fluvial or lacustrine ice-contact melt-water deposits. Most of the deformation structures exposed in nearly all the ice-contact heads in scores of mapped morphosequences resulted essentially from collapse due to melting of adjacent or buried motionless ice. The only ice-contact heads of outwash that indicate the presence of live ice are those associated with end moraines, which are very scarce except in the coastal areas of New England. The collapse structures include normal faults, high-angle reverse faults, slumps, and debris flows. In some graben structures, the upper parts of the fault planes curve over the downdropped blocks and become reverse faults (fig. 4). In some exposures, only the upper curved parts of such faults are exposed, giving an appearance of overthrusting that possibly could be confused with ice shove. However, the collapse origin of these types of structures becomes clear for the most part at depth. McDonald and Shilts (1975) described many such normal and reverse faults resulting from collapse due to melting ice in glaciofluvial sediments. Stone (1976) described extraordinarily complex slump features (fig. 5) caused by melting of ice in glacial-lake sediments. These are just a few examples of faults and slumps that demonstrate the prevailing style of deformation throughout the region: this style of deformation strongly indicates that the ice margin was stagnant where it was in contact with morphosequences in a variety of depositional environments.

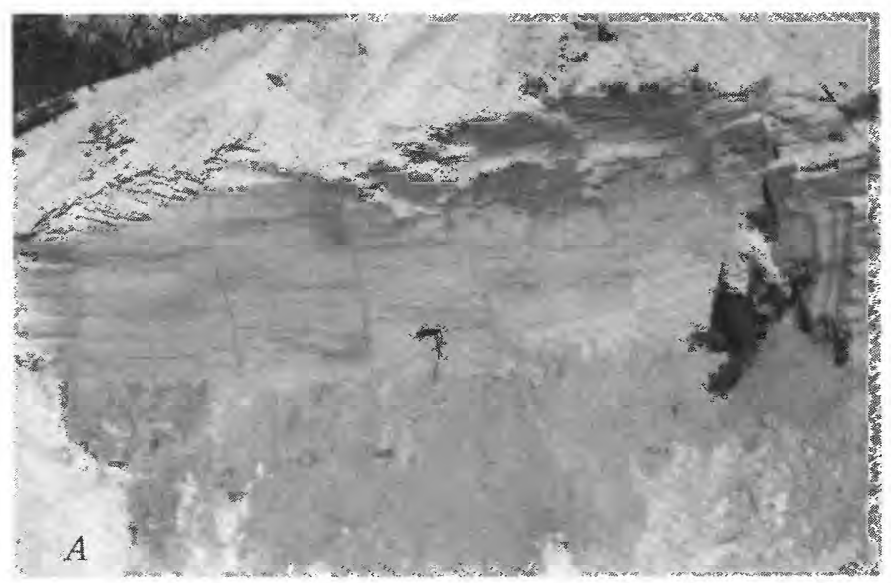

Figure 4.-Fault structures in two areas of collapsed glacial-lake sediments, Merrimack, N. H.; the collapse resulted from melting of buried ice. $A$, Curve of faults becomes less toward the center of collapse to the left. $B$, Downdropped sediments are to the right of the curving fault.
The heads of outwash of sequences laid down beyond the ice margin contain either few or no collapse features, depending on the relative abundance of stray, detached, ice blocks. No evidence of ice-shove or live-ice structures has been found either in the upstream areas of such sequences or at the presumed ice margin from which these deposits originated.

Although most morphosequences were laid down at and beyond the edge of the stagnant margin of the glacier, water-laid bodies deposited completely within the stagnant-ice zone are present in many places. The stagnation-zone deposits near Springfield, Mass. (fig.3), for example, contain sand, gravel, and flowtill that show only collapse structures. These and other similar deposits appear to represent sedimentation entirely within, and having a base level controlled by, stagnant ice. In contrast, most morphosequences have headward parts that were laid down within the stagnant zone, but had base levels beyond the ice edge, suggesting that

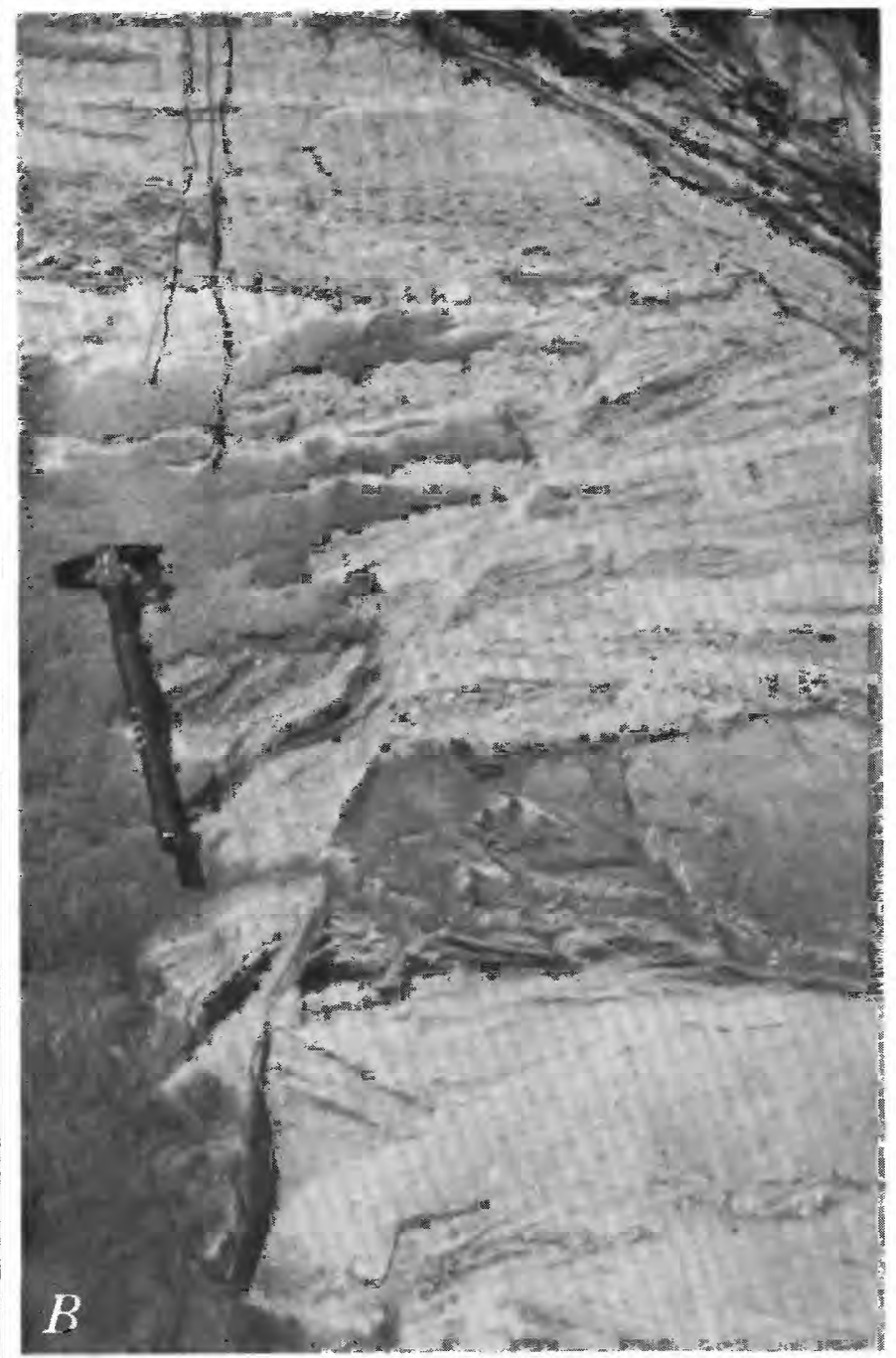




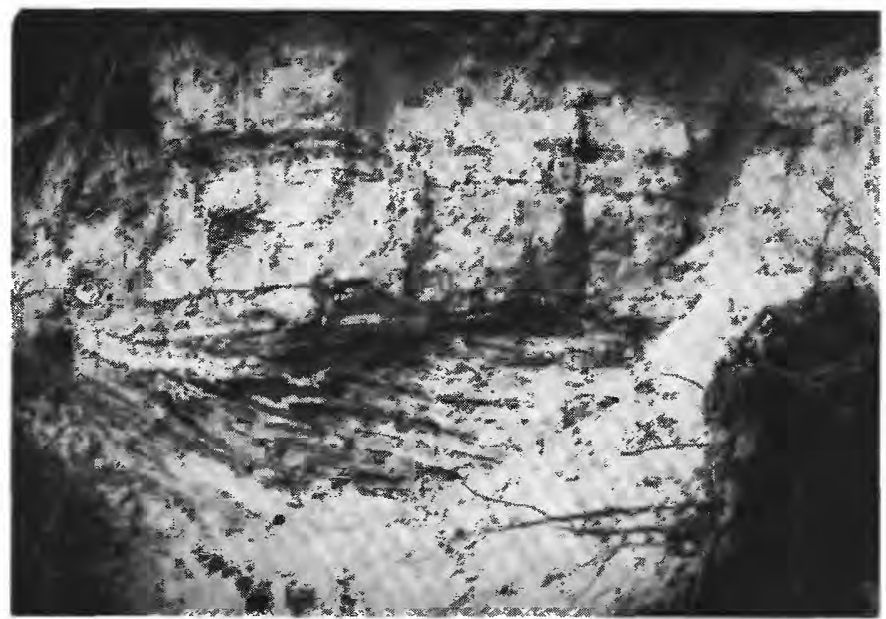

Figure 5.-Slump features in sediments of glacial Lake Merrimack, Manchester, N. H. Folding and shearing probably were caused by melting of buried ice to the left of the section. Note later undisturbed sediments over slumped features. Photograph by Byron D. Stone.

most melt-water drainage within the stagnant zone was integrated with that of the ice-free proglacial areas.

\section{EVIDENCE FOR THE PRESENCE OF LIVE ICE}

\section{DEFINITION OF END MORAINE}

The terms "moraine" and "end moraine" often have been used ambiguously to describe various features in New England that were constructed at the edge of an ice sheet. This ambiguity has hampered discussions on the regimen of the ice sheet during recession. For example, the term "kame moraine" has been applied to deposits in southeastern Massachusetts that no doubt were laid down entirely within the stagnant zone. As mentioned above, Alden (1924) used the word "moraine" to describe what are now viewed as ice-contact meltwater deposits. Large bodies of melt-water deposits in the St. Lawrence Valley in Canada and in the Finger Lakes region in New York are referred to as moraines. Although these are very striking features, large parts of them appear to be parts of one or another type of morphosequence.

On the other hand, the word "moraine" has been more properly used in describing features associated with or built at the edge of live ice in many places. Therefore, within the conceptual framework of the morphosequence model and stagnation-zone retreat, it seems more appropriate that the terms "moraine" and "end moraine" be applied only to features that were constructed, at least in part, by live ice, so as to distinguish them from morphosequences and stagnant-zone meltwater deposits. Such a distinction is important because knowledge of the distribution of live ice relative to the stagnant margin during ice retreat helps us to understand the glacier regimen.

\section{LOCALITIES OF LIVE-ICE FEATURES}

Although the physical characteristics and positions of most melt-water deposits in New England suggest that a predominantly stagnant marginal zone was part of the receding ice sheet, a few localities inland from the coastal areas indicate that live ice either constructed end moraines or readvanced over melt-water deposits at various times during general ice recession. The bulk of the well-known morainal system that stretches from Long Island, N.Y., to Cape Cod, Mass. (fig. 6), appears to have been formed near the maximum extent of the glacier, which roughly coincides with the coastal areas of southern New England. Even on this large scale, topographic control of ice lobation and related deposits is very evident; the pronounced eastward lobation of the morainal belt was due to the successively deeper topographic basins in that direction. Well-defined moraines also have been identified parallel to and along the coast of Maine (Borns, 1968). Inland from the coast, the few known end moraines (fig. 6) include the Fresh Pond moraine (Chute, 1959) near Boston, a small end moraine near Hardwick, Mass., and a very short, segment of a probable end moraine near South Coventry, Conn. The South Coventry feature has been interpreted as a melt-water deposit laid down in a system of regionally stagnating ice (Black and Frankel, 1976; Black, 1977), but the presence of till and the morphology of the ridge there suggest that it is rather a moraine constructed at least in part by live ice. Thompson (1976) described some hitherto unknown moraines inland from coastal Maine in Kennebec County.

Readvance localities (fig. 6) not associated with end moraines include the Middletown readvance in the Connecticut River valley (Flint, 1953), a readvance near Mt. Tom, Mass. (Larsen, 1972), and a minor readvance near Manchester, N.H. (Stone and Koteff, 1979). The Manchester locality shows till overlying sheared and deformed lake-bottom sediments (fig. 7) and is interpreted as a minor local pulse of the ice sheet over deposits of glacial Lake Merrimack, which occupied south-central New Hampshire during the general retreat of the last glacier. Lougee (1935) described a readvance farther north, near East Barnet, Vt., over varved clays deposited in glacial Lake Hitchcock. Connally (1970) demonstrated that to the west, ice readvanced near Bridport, Vt. Bloom (1960) reported a readvance over marine sediments along the southwest coast of Maine.

These localities are most of the known, welldocumented examples of end moraines and ice readvances. Other possible readvance localities in New Hampshire were recorded by Upham (1878) and Crosby (1934), but were later dismissed by Goldthwait (1938). Whether these localities are actual readvance sites, 


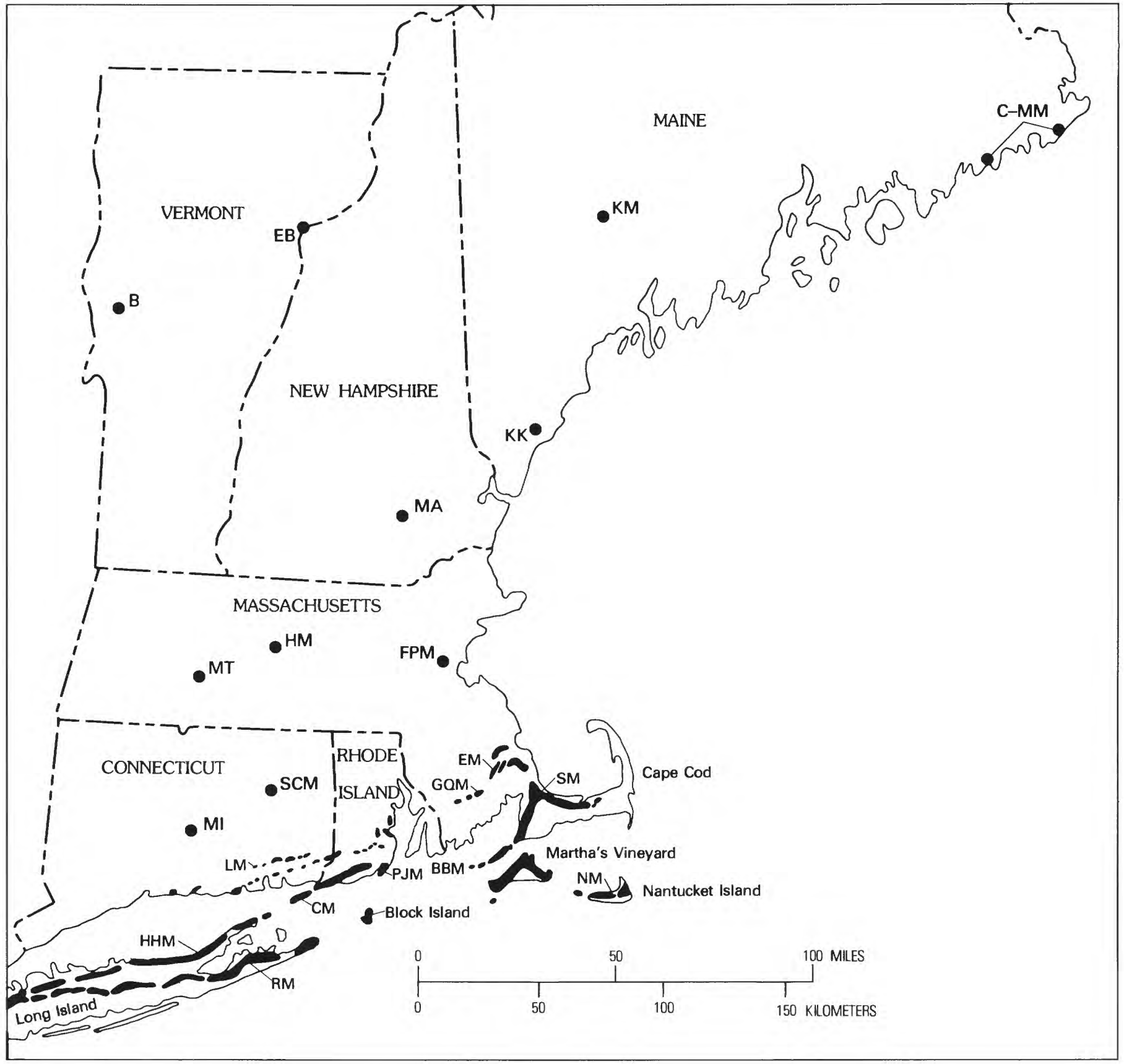

Flgure: 6. -Distribution of Wisconsinan moraines and ice-readvance localities in New England, $B$, Bridport readvance; $B B M$, Buzzards Bay moraine; $C M$, Charlestown moraine; $C-M M$, Cherryfield to Machias moraines; $E B$, East Barnet readvance; $E M$, Ellisville moraine; $F P M$, Fresh Pond moraine; GQM, Great Quittacas Pond moraine; HHM, Harbor Hill moraine; HM, Hardwick moraine; KM, Kennebec moraines; $K K$, Kennebunk readvance; $L M$, Ledyard moraine; $M A$, Manchester readvance; $M I$, Middletown readvance; $M T$, Mount Tom readvance; $N M$, Nantucket moraine; PJM, Point Judith moraine; RM, Ronkonkoma moraine; SCM, South Coventry moraine; SM, Sandwich moraine. Moraines on Long Island and along southern New England coast modified from Schafer and Hartshorn (1965). 


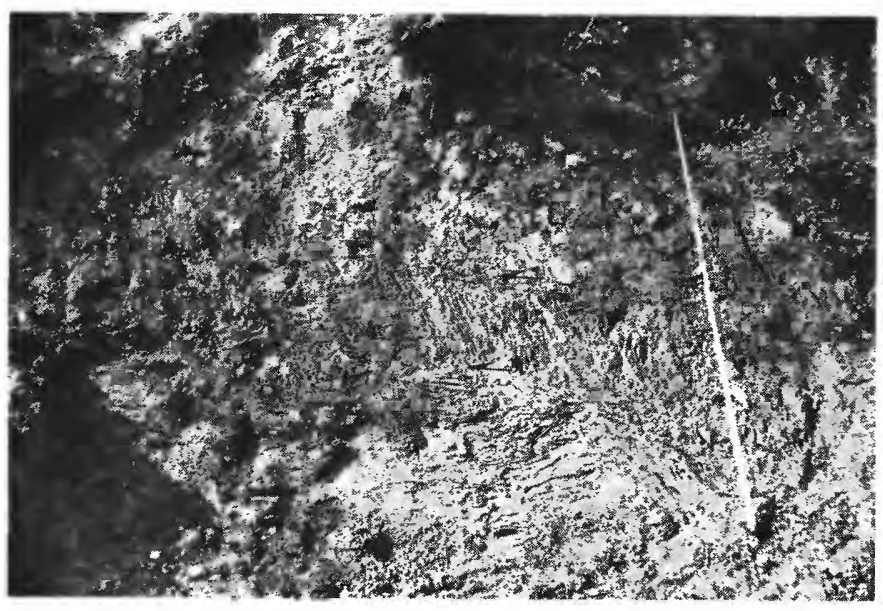

Figure 7.-Till overlying sheared and rotated glacial-lake bottom sediments, Manchester, N.H. Relative movement from right to left. Photograph by Grahame J. Larson.

therefore, remains in doubt. Although, almost assuredly, other places in New England show evidence of an active edge to the retreating Laurentide ice sheet, the relative scarcity of such localities is apparent throughout New England. All the well documented inland recessional moraines and readvance localities are interpreted as strictly local features. That is, the distance covered by any single readvance, although not precisely known, is probably not more than a few kilometers (Larsen, 1972; Stone and Koteff, 1979). In a regionally stagnating system, however, a very large area of ice (of regional proportions) would have to be reactivated for each readvance; each readvance would be followed by an interlude of stagnation. The widespread distribution of the known localities, scarce as they are, and the apparent short distances involved in the ice readvances indicate that live ice was never far from the stagnant margin during deglaciation.

\section{MODE OF ICE RETREAT}

Morphosequences have been recognized and mapped in many parts of southern, central, and northern New England, in large and small depositional basins, as well as in many upland areas. Because of the relative scarcity of live-ice features such as end moraines and readvance localities away from the coast, the only indicators of retreatal ice-margin positions in most of the region are the outwash heads of the sequences themselves. The abundance of morphosequences and the scarcity of localities that demonstrate a live-ice edge suggest that a zone of stagnant ice bordered the live ice of the continental glacier and acted as a buffer between the active ice and melt-water deposits. This model is called "stagnation-zone retreat" (Currier, 1941).
The width of the stagnant zone is not well known, but can be estimated from the length of eskers or icechannel fillings that served as feeders to melt-water deposits within a single sequence. In New England, all ice-channel fillings, some of which are as much as $2.5 \mathrm{~km}$ long (Koteff, 1974), show collapse structures indicative of contact with stagnant ice. However wide the stagnant zone was, it appears to have been a persistent feature of the receding ice sheet in the region.

The careful study of hundreds of morphosequences in scores of inland quadrangles within southern New England demonstrates a systematic and chronologic relationship among sequences; this relationship, in turn, indicates that the northward retreat of the last ice sheet was systematic and was interrupted by only a few pauses or small readvances at scattered localities throughout the region. This systematic relationship is illustrated by the shingled profiles of sequences in drainage areas such as those shown in figure 2; it is perhaps even better illustrated by the shingled profiles of deltas in glacial lakes, particularly of deltas deposited in glacial lakes that were maintained at the same level for a considerable time. For example, figure 8 outlines profiles of several successive deltas laid down during the Clinton stage of glacial Lake Nashua in north-central Massachusetts. This lake was held at the same level by a bedrock spillway for the amount of time it took for the ice margin to recede north more than $13 \mathrm{~km}$. The topset fluvial part of each of these deltas shows a general textural gradation of relatively coarser clast sizes at the icemarginal head to finer downstream. The combination of a persistent lake with several deltas of melt-water deposits that are graded to a constant water level, that show en echelon or shingled profiles, and that have coarse clasts upstream and smaller particles downstream can best be explained by systematic ice retreat.

\section{THE DIRT MACHINE}

In previous discussions on whether deglaciation in New England was accomplished by regional stagnation or systematic ice retreat, little attention was given to the source of debris washed out of glacier ice by meltwater streams. However, ideas on the source of this sediment, whether from stagnant ice or from actively flowing ice, are closely related to ideas concerning the mode of ice retreat. The morphosequence concept has led to a view of debris origin that favors systematic ice retreat rather than regional stagnation.

Regional stagnation requires that the motionless ice, covering vast areas, contained enough material to supply the large amounts of sediment deposited by meltwater streams during general ice wastage. Much of the 

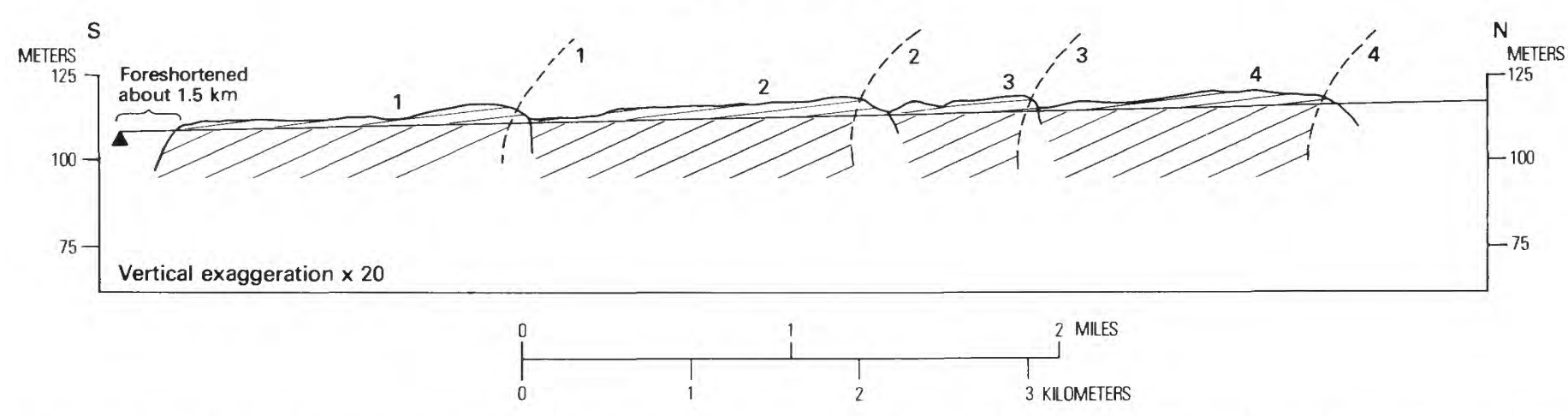

Figure 8.-Profiles of four successively younger lacustrine ice-contact sequences (kame deltas) in the Clinton quadrangle, Mass. Sequence 1 is the oldest. Solid triangle represents bedrock spillway. Dashed lines indicate approximate edges of stagnant ice. Modified from Koteff (1966).
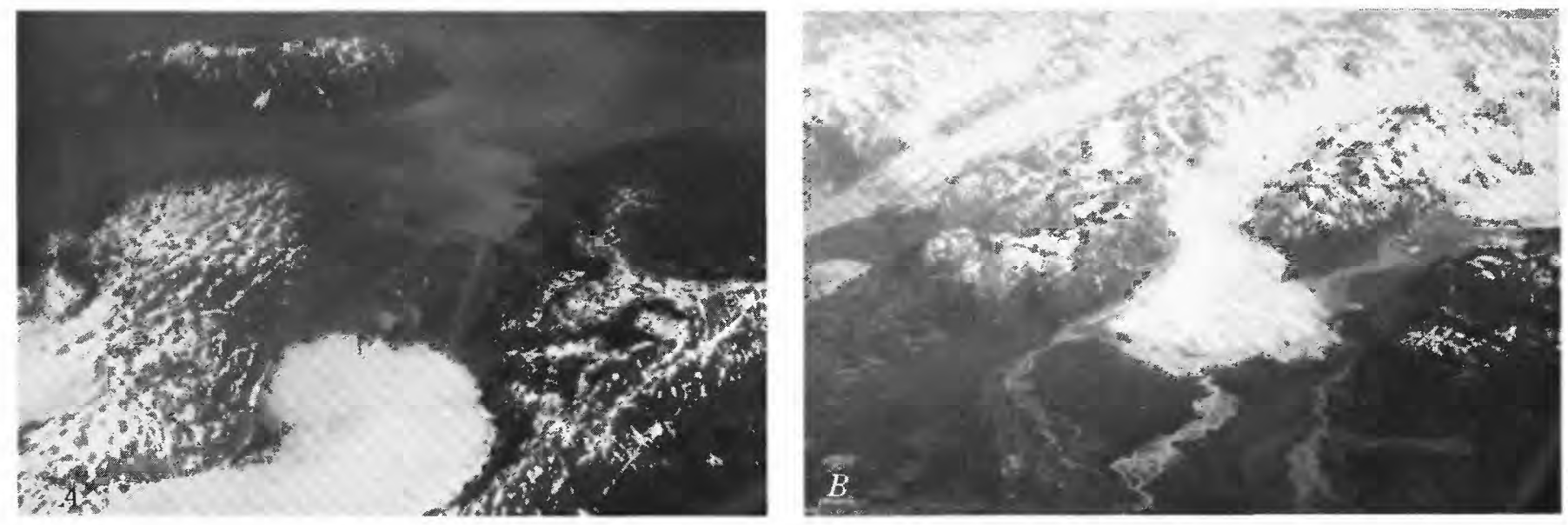

Figi're 9.-Debris-rich terminal zones and clean ice upglacier to the firn line in modern glaciers. $A$, Tebenkof Glacier near Whittier, Alaska. $B$, From left to right, Scott Glacier, Sheridan Glacier, and Sherman Glacier near Cordova, Alaska. Wide area of debris covering on Sherman Glacier snout resulted from landslide during earthquake of March 27, 1964 (Shreve, 1966). Photographs taken August 1975.

material would have had to be distributed in englacial or superglacial positions to account for the present positions and altitudes of melt-water deposits. Most studies of debris transport by glaciers, however, indicate that the bulk of material is carried at the base or in the lower few meters of ice sheets (Goldthwait, 1971; Boulton, Dent, and Morris, 1974; Boulton, 1975). Present valley glaciers (for example, in Alaska) also seem to be extremely dirty or debris laden only at their snouts (fig. 9). If any of these valley glaciers, and, by analogy, continental glaciers, were suddenly to stagnate and dissipate, the major debris source would be in the basal parts and at the snout or edge, but not in any other part of the glacier. The altitude, position, and volume of morphosequences in New England suggest that regional stagnation is unlikely to have supplied the debris necessary to account for their systematic and widespread distribution. Many thick morphosequences are found all across the area and not just at the hypothetical edge of a regionally stagnating ice sheet.
Superglacial debris such as scree or other material derived by mass movement from adjacent valley walls is found locally on the surface of most present-day alpine glaciers (fig. 10), and debris produced by similar processes can be considered as a possible source for outwash deposits from a regionally stagnating glacier. In many areas of New England, however, the altitude of morphosequences and the large sediment volume within them are not consistent with this concept. For example, most of the preglacial landscape of southeastern Massachusetts and of many parts of Rhode Island is completely overwhelmed by water-laid deposits whose lithologic composition strongly reflects the local bedrock. These deposits are at altitudes much greater than those of the highest local bedrock; thus, there was no high source area from which rock debris could move down onto the surface of the ice and subsequently be washed out by streams. Furthermore, the volumes of water-laid drift in New England appear to be much larger than volumes that could have come from such 


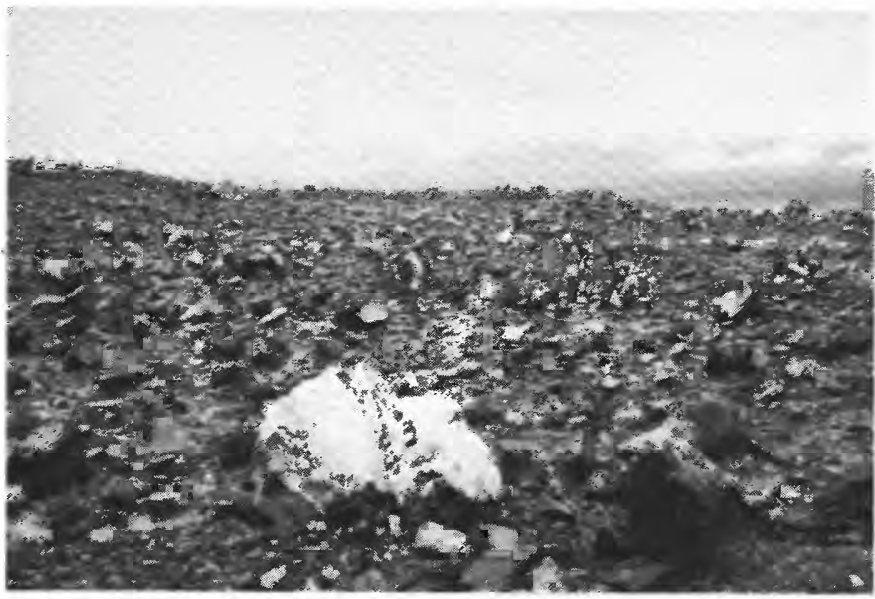

Figure 10.-Scree on the Casement Glacier, Glacier Bay National Monument, Alaska. Figure in center of picture indicates scale. Photograph taken July 1975.

surface debris, even where it may have accumulated locally. Scree on the surface of some existing valley glaciers has an imposing appearance, but is only a very thin surface layer where present (fig. 11) and, therefore, seems a very unlikely source of large amounts of debris.

A process that appears to account for the large volumes of material that compose morphosequences and that is compatible with the systematic distribution of sequences is one in which the live ice continuously moves forward and is sheared up against the motionless marginal belt of the stagnant zone (fig. 12). Thinning of the ice sheet at the edge accompanying general recession results either in marginal ice no longer thick enough to support forward motion or in a significantly reduced rate of motion in this zone. The marginal ice then becomes an obstruction to the faster moving ice

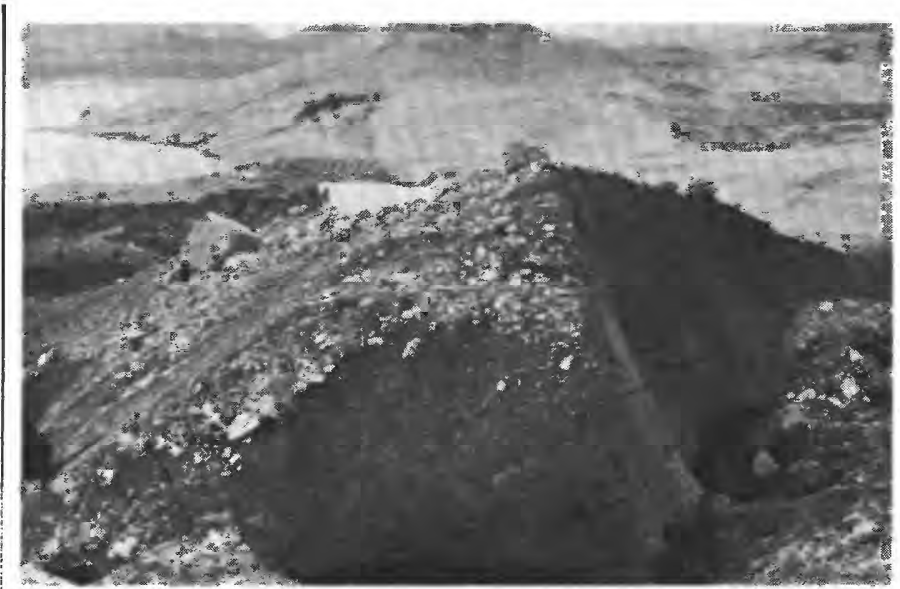

FIGURE 11.-Detached ice block, Casement Glacier, showing only thin surface covering of debris. Sides of the block have been partly covered by mud flowing from the ice surface during melting. Photograph taken July 1975.

behind it, forcing the upward shearing of the live ice, and tending to further promote stagnation of the slower moving ice. Abraded material transported at the base of the ice is carried upward toward the surface along these shear planes.

During continuous retreat, the zone of active shearing migrates up ice, leaving behind debris-laden relict shear planes in the stagnant zone. As the ice melts, the debris in the relict shear planes is concentrated at the stagnant margin. Melt-water streams, principally from the surface of the live ice, pass through the concentration of debris, picking up material and depositing it in, and mostly beyond, the stagnant zone as morphosequences. Pebble lithologies indicate that most outwash clasts in New England were transported no more than a few kilometers from the bedrock source. Thus, the zone of

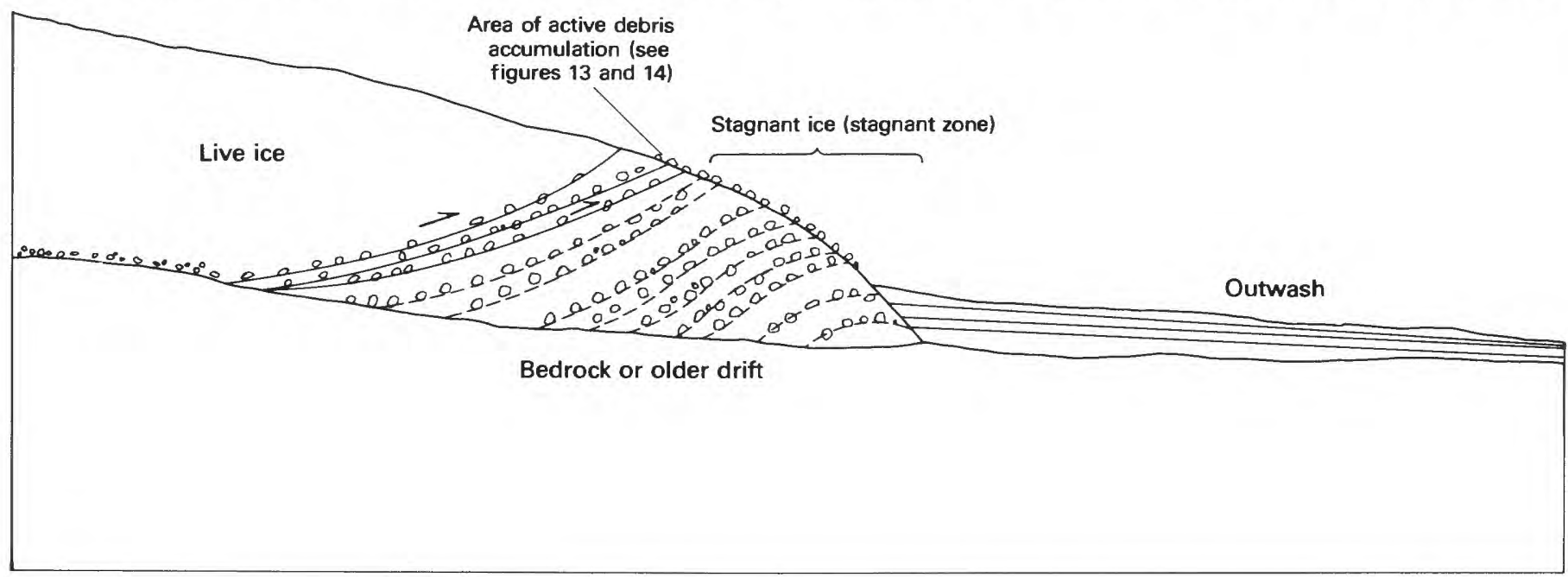

FIGURE 12.-Diagrammatic profile of margin of retreating ice. Solid lines (arrows) indicate shear planes along the live-ice/stagnant-ice interface; dashed lines in the stagnant zone indicate relict shear planes of former live-ice/stagnant-ice interfaces. 
maximum ice abrasion probably was not very far from the margin of the glacier throughout deglaciation. Whatever debris that was not reworked and carried out beyond the stagnant zone by fluvial action probably ended up mostly as ablation till, let down as the motionless ice melted away. Very qualitative observations indicate that most of the surface till in New England was transported no more than about $1.5 \mathrm{~km}$ from its bedrock source. This small transport distance also suggests that the zone of maximum abrasion was near the edge of the live ice.

The extreme angularity of scree, such as that found on the Casement Glacier (fig. 10), also appears to preclude scree as a significant source of material. Although scattered local postglacial talus accumulations have very angluar clasts, very few of the boulders and stones of the till landscape of New England, including all areas of superglacial till, approach the degree of angularity found in modern analogs such as the Casement Glacier.

Features interpreted to be shear planes were found near the distal parts of the Casement Glacier in 1975, slightly up ice from the stagnant margin (figs. 13 and 14). The shear planes contain boulder-size to silt-size clasts. The roundness of the clasts in these shear planes, which may have resulted from abrasive transport at the base of the glacier, is much greater than that of clasts in the scree shown in figure 10 , which is merely riding along on the glacier surface. No quantitative data are available on the amounts of material that could have been brought up along such shear planes; however, we do see that only the distal part of the Casement Glacier (fig. 15) contains appreciable debris.

The idea that debris is carried upward along shear planes at the live-ice/stagnant-ice interface of a glacier is certainly not new, and we think it readily explains present altitudes and thicknesses of morphosequences found in New England where no higher source now exists. The continuous process of forward-moving ice supplying debris for redistribution by melt-water streams also appears to explain the enormous volumes of sand, gravel, silt, and clay now found in sequences throughout New England. The live ice acting as a conveyor belt, constantly delivering material to the stagnant zone, has been referred to as the "dirt machine" (Koteff, 1974).

\section{SUMMARY}

The long-standing controversy over the nature of recession of the last ice sheet to overrun New England, whether by regional stagnation or "normal" retreat, became more sharply focused by the work of R. H. Jahns in the early 1940 's. This work, on newly introduced, detailed topographic base maps, and later studies, chiefly by members of the U.S. Geological Survey, began to shift the weight of the argument toward the view of normal retreat, at the same time incorporating some aspects of regional stagnation such as the presence of a stagnant zone at the margin of a systematically receding ice sheet. The model, now called the morphosequence concept, demonstrates the presence of numerous retreatal ice-margin positions. The importance of topographic control of the distribution of melt-water sediments is emphasized, rather than the effects of climatically controlled stillstands of the continental glacier. Furthermore, the distribution, altitude, and volume of melt-water deposits strongly suggest that live ice delivered abraded material from below, up along shear planes at the live-ice/stagnant-ice interface, as a continuous process during retreat. Direct melting out of rock debris from stagnant ice masses contributed only minor amounts of sediment to the glacial melt-water deposits.

The relatively narrow width of the stagnant zone is defined according to maximum length of elongate icecontact forms such as eskers and ice-channel fillings at the heads of individual sequences. The proximity of active glacier ice to the stagnant zone during deglaciation is suggested by the relatively few, but widely scattered, localities at which end moraines or evidence of minor glacier readvances are present.

Detailed surficial mapping of $71 / 2$-min quadrangles over all major parts of southern and central New England has shown the widespread distribution of morphosequences and their relation to ice margins during deglaciation, and has demonstrated that the Laurentide ice sheet retreated systematically northward by the process of stagnation-zone retreat. 

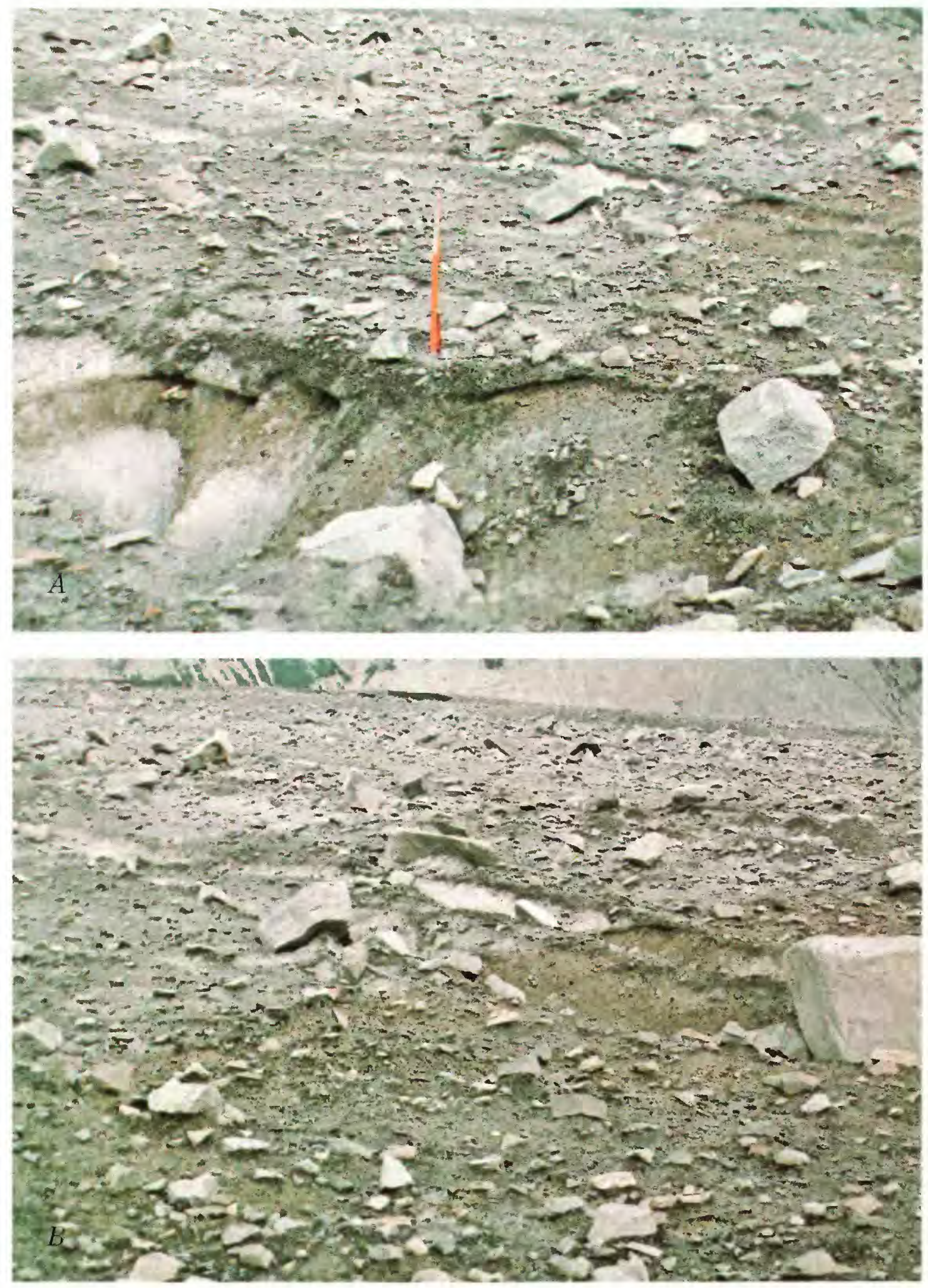

Figure 13.--Shear planes containing debris, Casement Glacier. $A$, Axe at intersection of shear plane with ice surface. Iron-rich debris, derived from a local source, traveled up shear plane dipping to left. $B$, Extension of shear-plane intersection with the ice surface. Iron-rich debris contrasts with gray scree carried along the ice surface. 

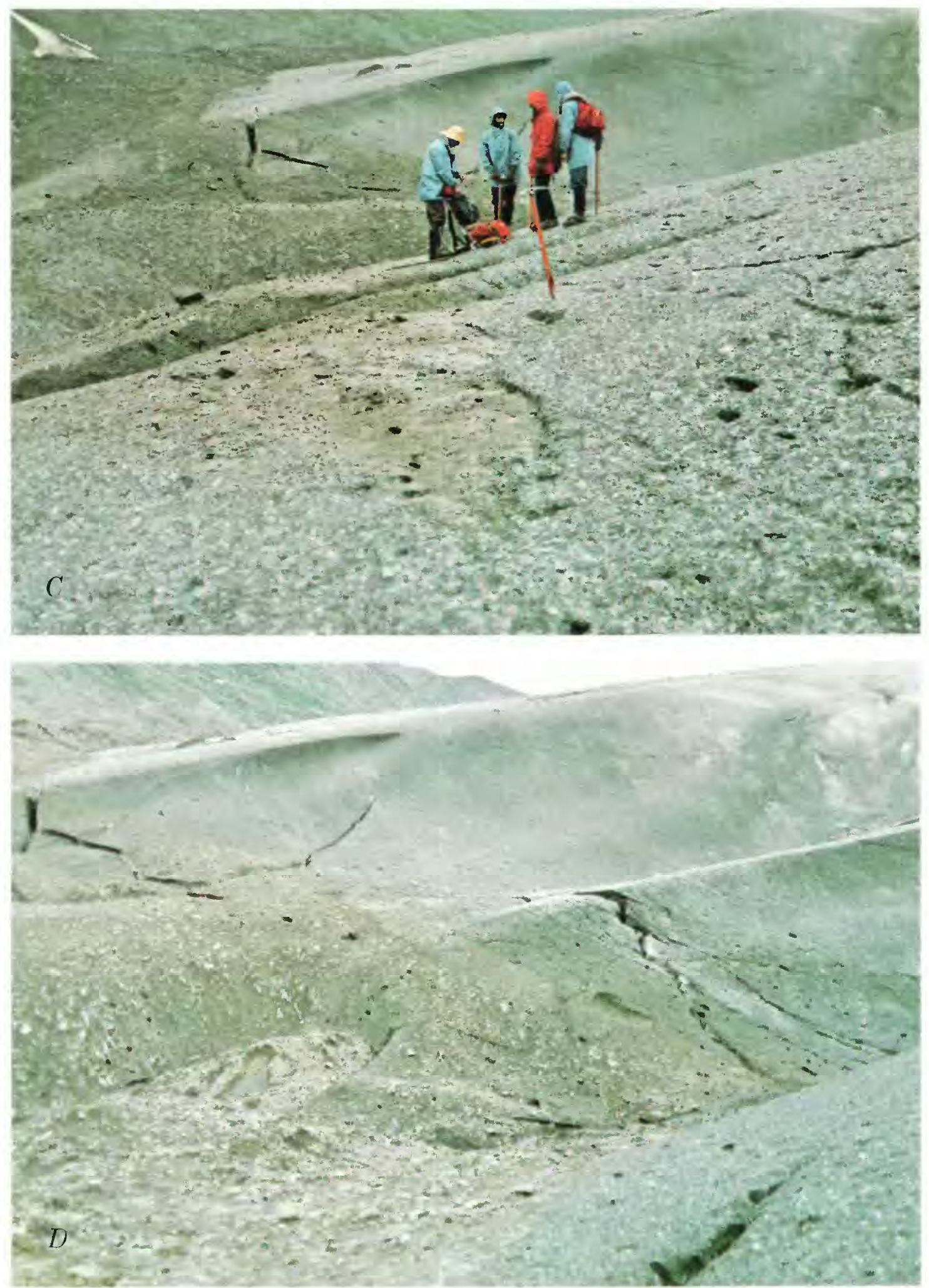

Figure 13.-Continued. $C$ and $D$, Shear planes containing locally derived iron-rich debris in an area of the Casement Glacier where scree is absent. Shear zone appears to pinch out in foreground of $C$. Moraine in distance has a core of ice. Shear planes in $C$ and $D$ dip to the right. Photographs taken July 1975. 


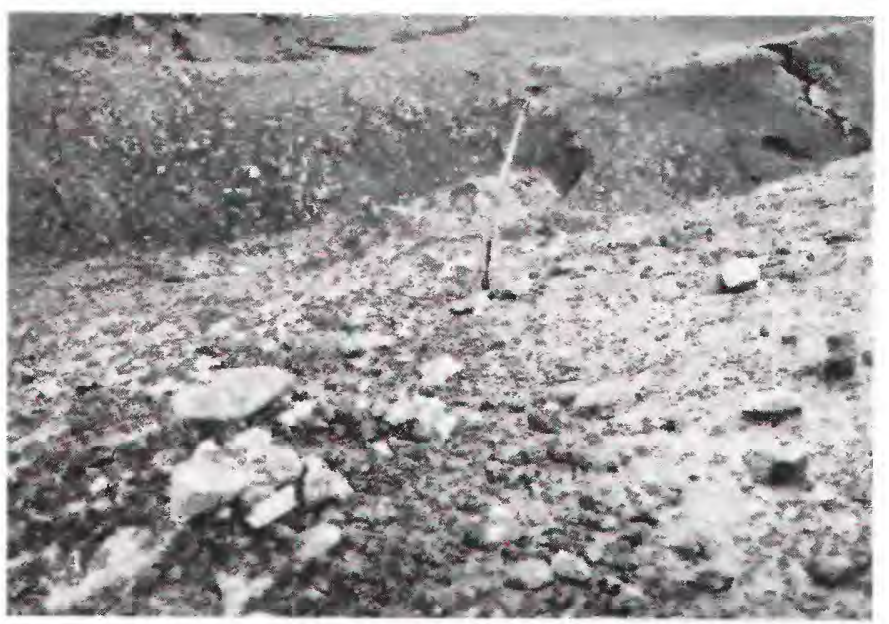

Figure 14.-Debris on Casement Glacier derived from shear planes near the area shown in figure 13. A, Axe on intersection of glacier surface and shear plane that dips sharply up ice to the right. Debris is concentrated left of the axe, and the surface debris zone can be traced toward the viewer.

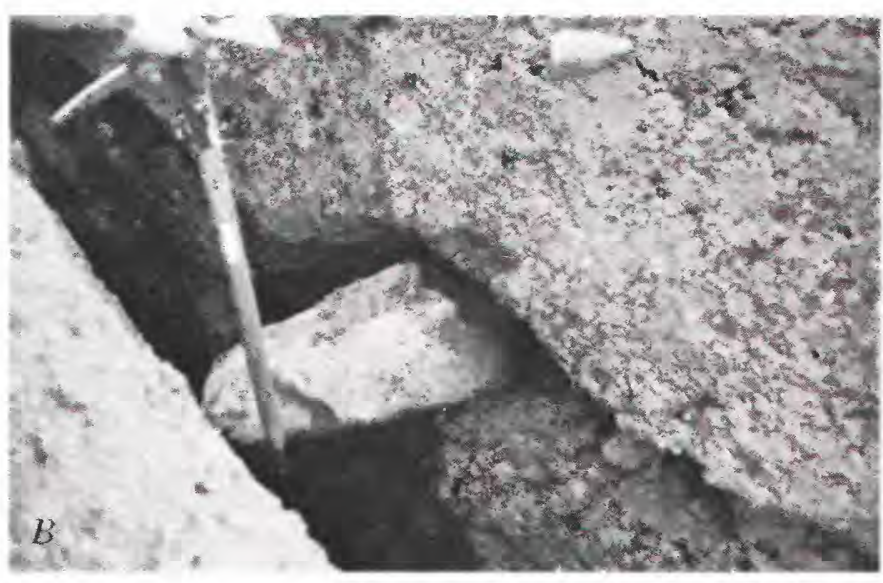

Figure 14.-Continued. $B$, Shear plane in ice dipping to the left. Note that the large clasts along the shear plane are much rounder than the clasts in the scree shown in figure 10. Photographs taken July 1975.

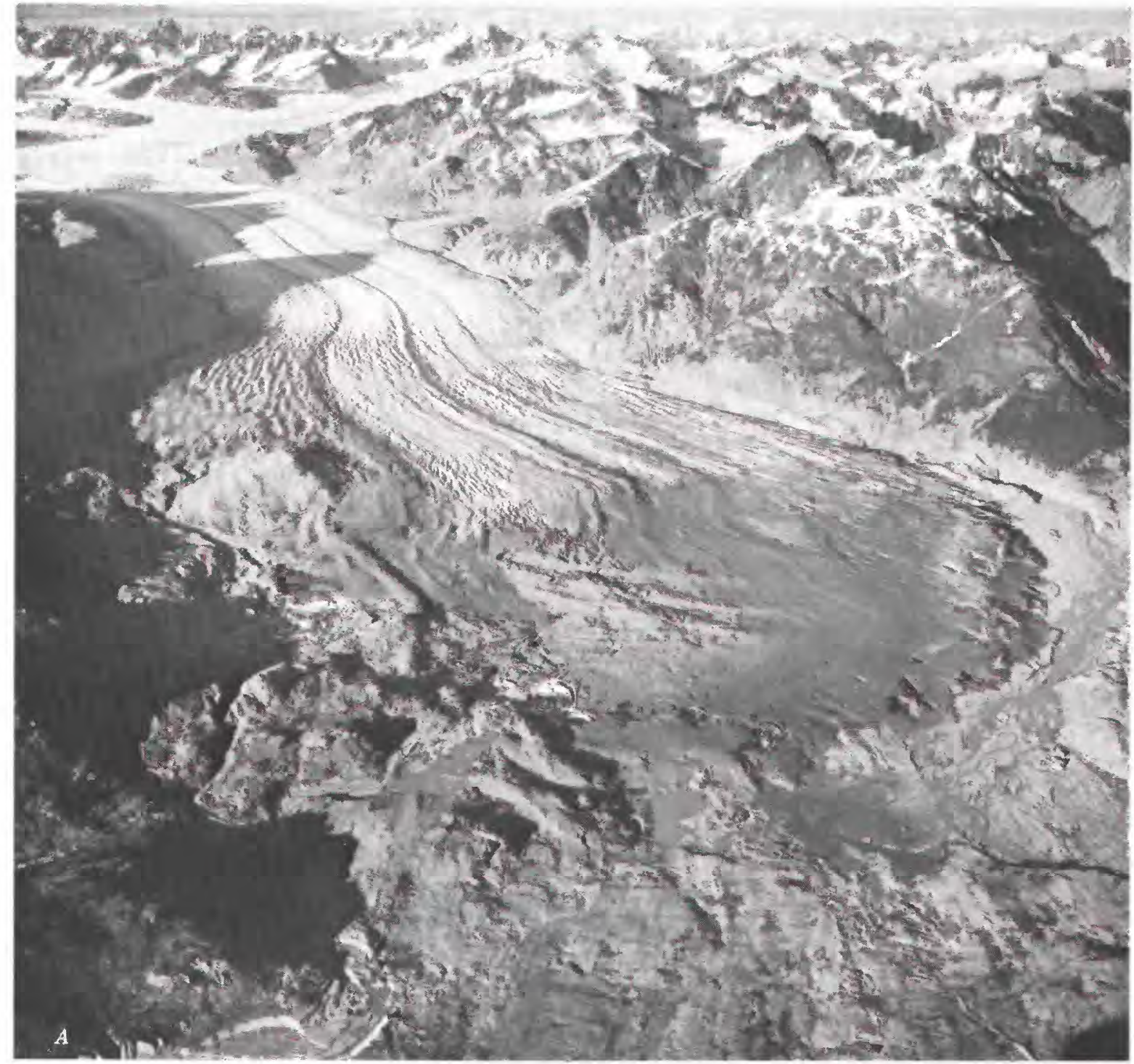

Figure 15.-Casement Glacier. A, Looking southeast. Photograph by Austin Post, August 1964. B, Looking northeast. Photograph taken 1975. Morainal debris near center of the glacier is a thin surface accumulation. Debris covering the area at the edge of the glacier is interpreted as having been derived chiefly from the dirt machine, as explained in the text. 


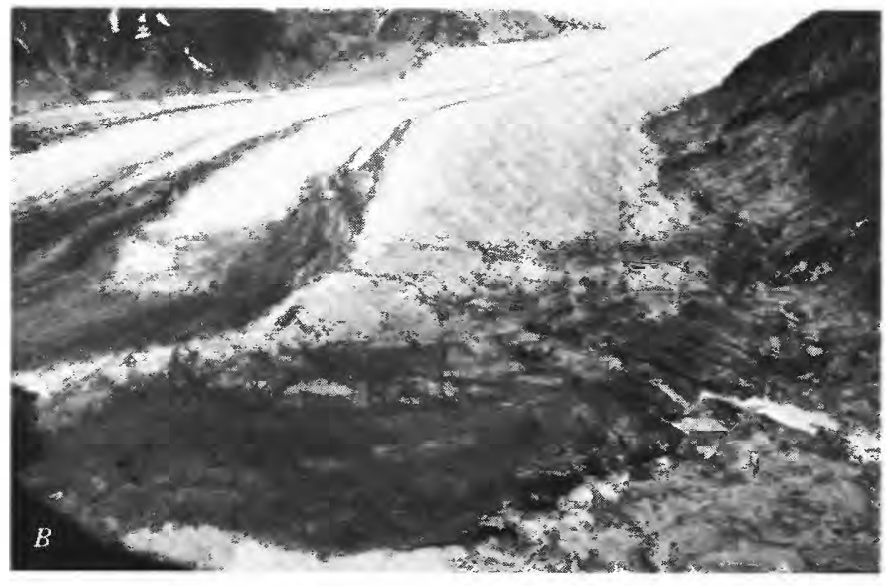

Figure 15.-Continued.

\section{REFERENCES CITED}

Alden, W. C., 1924, The physical features of central Massachusetts: U.S. Geological Survey Bulletin 760-B, p. 13-105.

Antevs, Ernst, 1922, The recession of the last ice sheet in New England: American Geographical Society Research Series No. 11, $120 \mathrm{p}$.

- 1939, Modes of retreat of the Pleistocene ice sheets: Journal of Geology, v. 47, no. 5, p. 503-508.

Black, R. F., 1977, Regional stagnation of ice in northeastern Connecticut; An alternative model of deglaciation for part of New England: Geological Society of America Bulletin, v. 88, no. 9, p. 1331-1336.

Black, R. F., and Frankel, Larry, 1976, Deglaciation of the Shetucket River basin, northeastern Connecticut: Geological Society of America Abstracts with Programs, v. 8, no. 2, p. 135-136.

Bloom, A. L., 1960, Late Pleistocene changes of sealevel in southwestern Maine: Augusta, Maine, Maine Geological Survey, $143 \mathrm{p}$.

Borns, H. W., Jr., 1968, End-moraine complex in southeastern Maine [abs]: Geological Society of America Special Paper 101, p. 249-250.

Boulton, G. S., 1975, Processes and patterns of subglacial sedimentation; a theoretical approach, in Wright, A. E., and Moseley, F., eds., Ice ages, ancient and modern: Geological Journal, Special Issue 6, p. 7-42.

Boulton, G. S., Dent, D. L., and Morris, E. M., 1974, Subglacial shearing and crushing, and the role of water pressures in tills from southeast Iceland: Geografiska Annaler, Ser. A, v. 56A, no. 3-4, p. 135-145.

Chute, N. E., 1959, Glacial geology of the Mystic Lakes-Fresh Pond area, Massachusetts: U.S. Geological Survey Bulletin 1061-F, p. 187-216.

Clapp, F. G., 1904, Relations of gravel deposits in the northern part of glacial Lake Charles, Massachusetts: Journal of Geology, v. 12, no. 3, p. 198-214.

Connally, G. G., 1970, Surficial geology of the Brandon-Ticonderoga 15-minute quadrangles, Vermont: Vermont Geological Survey Studies in Vermont Geology, no. 2, 32 p.

Cook, J. H., 1924, The disappearance of the last glacial ice sheet from eastern New York: New York State Museum Bulletin 251, p. 158-176.

Crosby, I. B., 1934, Extension of the Bethlehem, New Hampshire, moraine: Journal of Geology, v. 42, no. 4, p. 411-421.
Crosby, W. O., 1899, Geological history of the Nashua Valley during the Tertiary and Quaternary Periods: Technology Quarterly, v. 12, no. 4 , p. 288-324.

Currier, L. W., 1941, Disappearance of the last ice sheet in Massachusetts by stagnation zone retreat [abs.]: Geological Society of America Bulletin, v. 52, no. 12, pt. 2, p. 1895.

Dana, J. D., 1873, On the glacial and Champlain eras in New England: American Journal of Science, 3d ser., v. 5, p. 198-211, 217-219.

Emerson, B. K., 1898, Geology of old Hampshire County, Massachusetts: U.S. Geological Survey Monograph 29, 790 p.

Flint, R. F., 1928, Eskers and crevasse fillings: American Journal of Science, 5 th ser., v. 15 , p. 410-416. 1929, The stagnation and dissipation of the last ice sheet: Geographical Review, v. 19, no. 2, p. 256-289.

1930, The glacial geology of Connecticut: Connecticut State Geological and Natural History Survey Bulletin 47, $294 \mathrm{p}$. 1932, Deglaciation of the Connecticut Valley: American Journal of Science, 5th ser., v. 24, p. 152-156.

1933, Late Pleistocene sequence in the Connecticut Valley: Geological Society of America Bulletin, v. 44, no. 5, p. 965-988.

1934, Late glacial features of the Quinnipiac-Farmington lowland in Connecticut: American Journal of Science, 5th ser., v. 27, no. 158 , p. 82-91.

1953, Probable Wisconsin substages and late-Wisconsin events in northeastern United States and southeastern Canada: Geological Society of America Bulletin, v. 64, no. 8, p. 897-919.

Flint, R. F., and Gebert, J. A., 1976, Latest Laurentide ice sheet; New evidence from southern New England: Geological Society of America Bulletin, v. 87, no. 2, p. 182-188.

Fuller, M. L., 1904, Ice-retreat in glacial Lake Neponset and in southeastern Massachusetts: Journal of Geology, v. 12, no. 3, p. 181-197.

1914, The geology of Long Island, New York: U.S. Geological Survey Professional Paper 82, $231 \mathrm{p}$.

Goldthwait, J. W., 1905, The sand plains of glacial Lake Sudbury: Harvard College Museum of Comparative Zoology Bulletin, v. 42 (Geological Series, v. 6, no. 6), p. 261-301.

1925, The geology of New Hampshire: New Hampshire Academy of Science Handbook no. 1, 86 p.

1938, The uncovering of New Hampshire by the last ice sheet: American Journal of Science, 5th ser., v. 36, no. 215, p. 345-372.

Goldthwait, R. P., ed., 1971, Till; A symposium: Columbus, Ohio, Ohio State University Press, 402 p.

Hartshorn, J. H., and Koteff, Carl, 1967, Geologic map of the Springfield South quadrangle, Hampden County, Massachusetts, and Hartford and Tolland Counties, Connecticut: U.S. Geological Survey Geologic Quadrangle Map GQ-678, 4 p., 1 pl., scale 1:24,000.

Jahns, R. H., 1941, Outwash chronology in northeastern Massachusetts [abs]: Geological Society of America Bulletin, v. 52, no. 12 , pt. 2 , p. 1910 .

1953, Surficial geology of the Ayer quadrangle, Massachusetts: U.S. Geological Survey Geologic Quadrangle Map GQ-21, scale $1: 31,680$.

Jahns, R. H., and Willard, M. E., 1942, Late Pleistocene and Recent deposits in the Connecticut Valley, Massachusetts: American Journal of Science, v. 240, p. 161-191, 265-287.

Johnson, D. W., 1941, Normal ice retreat or down-wasting?: Journal of Geomorphology, v. 4, no. 1, p. 85-94.

Koteff, Carl, 1966, Surficial geologic map of the Clinton quadrangle, Worcester County, Massachusetts: U.S. Geological Survey Geologic Quadrangle Map GQ-567, 4 p., 1 pl., scale 1:24,000.

1974, The morphologic sequence concept and deglaciation of southern New England, in Coates, D. R., ed., Glacial geomorphology: Binghamton, N.Y., State University of New York, Publications in Geomorphology, p. 121-144. 
Koteff, Carl, and Volckmann, R. P., 1973, Surficial geologic map of the Pepperell quadrangle, Middlesex County, Massachusetts, and Hillsborough County, New Hampshire: U.S. Geological Survey Geologic Quadrangle Map GQ-1118, scale 1:24,000.

Langer, W. H., 1977, Surficial geologic map of the Glastonbury quadrangle, Hartford and Middlesex Counties, Connecticut: U.S. Geological Survey Geologic Quadrangle Map GQ-1354, scale $1: 24,000$

Larsen, F. D., 1972, Surficial geology of the Mount Tom quadrangle, Massachusetts: U.S. Geological Survey Open-File Report, 273 p., $4 \mathrm{pl}$.

Logan, Richard, 1938, Glacial history of the Housatonic Valley, western Massachusetts [abs.]: Association of American Geographers Annals, v. 28, no. 1, p. 55.

Lougee, R. J., 1935, Time measurements of an ice readvance at Littleton, New Hampshire: National Academy of Sciences Proceedings, v. 21, no. 1, p. 36-41.

1938, Physiography of the Quinnipiac-Farmington lowland in Connecticut: Colby College [Maine] Monograph 7, $64 \mathrm{p}$.

-1940, Deglaciation of New England: Journal of Geomorphology, v. 3 , no. 3 , p. $189-217$.

McDonald, B. C., and Shilts, W. W., 1975, Interpretation of faults in glaciofluvial sediments, in Jopling, A. V., and McDonald, B. C., eds., Glaciofluvial and glaciolacustrine sedimentation: Society of Economic Paleontologists and Mineralogists Special Publication 23, p. 123-131.

Mahaney, W. C., 1976, Preface, in Mahaney, W. C., ed., Quaternary stratigraphy of North America: Stroudsburg, Pa., Dowden, Hutchinson, and Ross, Inc., p. v-viii.

Oldale, R. N., 1974, Geologic map of the Dennis quadrangle, Barnstable County, Cape Cod, Massachusetts: U.S. Geological Survey Geologic Quadrangle Map GQ-1114, scale 1:24,000.

Rich, J. L., 1943, Buried stagnant ice as a normal product of a progressively retreating glacier in a hilly region: American Journal of Science, v. 241, no. 2, p. 95-100.

Salisbury, R. D., and others, 1902, The glacial geology of New Jersey,
Volume 5 of Final report of the State Geologist: Trenton, N.J., New Jersey Geological Survey, $802 \mathrm{p}$.

Schafer, J. P., 1961, Correlation of end moraines in southern Rhode Island: U.S. Geological Survey Professional Paper 424-D, p. D68-D70.

Schafer, J. P., and Hartshorn, J. H., 1965, The Quaternary of New England, in Wright, H. E., Jr., and Frey, D. G., eds., The Quaternary of the United States: Princeton, N. J., Princeton University Press, p. 113-128.

Shreve, R. L., 1966, Sherman landslide, Alaska: Science, v. 154, no. 3757 , p. $1639-1643$.

Stone, B. D., 1976, Analysis of slump slip lines and deformation fabric in slumped Pleistocene lake beds: Journal of Sedimentary Petrology, v. 46, no. 2, p. 313-325.

Stone, B. D., and Koteff, Carl, 1979, A late Wisconsinan ice readvance near Manchester, New Hampshire: American Journal of Science, v. 279 , p. $590-601$.

Stone, G. H., 1899, The glacial gravels of Maine and their associated deposits: U.S. Geological Survey Monograph 34, 499 p.

Taylor, F. B., 1931, Retreat of the front of the last ice sheet in New York and New England [abs.]: Geological Society of America Bulletin, v. 42, no. 1, p. 334.

Thompson, W. B., 1976, Late Wisconsinan end moraines in western Kennebec County, Maine [abs.]: Geological Society of America Abstracts with Programs, v. 8, no. 2, p. 286-287.

Thwaites, F. T., 1926, The origin and significance of pitted outwash: Journal of Geology, v. 34, no. 4, p. 308-319.

Upham, Warren, 1878, Modified drift in New Hampshire, in Hitchcock, C. H., 1878, The geology of New Hampshire; Pt. 3, Surface geology: Concord, N.H., v. 3, p. 3-176.

White, S. E., 1947, Two tills and the development of glacial drainage in the vicinity of Stafford Springs, Connecticut: American Journal of Science, v. 245, no. 12, p. 754-778.

Woodworth, J. B., 1898, Some glacial wash-plains of southern New England: Essex Institute Bulletin, v. 29 (1897), p. 71-119.

-1899, The ice contact in the classification of glacial deposits: American Geologist, v. 23, p. 80-86. 